\title{
STUDIESOF THE OTTOMANDOMAIN
}

Cilt: 7 Sayı: 13 Ağustos 2017

ISSN: 2147-5210

DOI Number: 10.19039/sotod.2017.63

Geliş Tarihi/Received: 05.07.2017

Kabul Tarihi/Accepted: 02.08.2017

\section{TARİHLİ 187 NOLU MEDRESE NÜFUS DEFTERINNE GÖRE İSTANBUL MEDRESELERİ NÜFUSU*}
THE POPULATION OF MADRASES OF ISTANBUL ACCORDING TO POPULATION BOOK OF ISTANBUL MADRASA 187 OF 1844

\author{
Aydın BOLAT ${ }^{1}$ \\ Pelin İSKENDER KILIÇ ${ }^{2}$
}

$\ddot{O} z$

Türk-İslam devletlerinde önemli bir eğitim kurumu olan medreseler, Osmanlı Devleti'nde de önemini korumuştur. $\mathrm{Bu}$ makalede, 1844 yılına ait 187 nolu İstanbul Medreseleri Nüfus Defteriyle ilgili bilgiler değerlendirilmeye çalışılmıştır. Defter, eldeki mevcut bilgilerle kısaca tanıtılmıştır. İstanbul medreseleri hakkında genel bilgi verilip, 1844 y1lı İstanbul medreselerine ait nüfus defterinin transkriptinden elde edilen bilgiler 1şığında defterde bulunan medresede yaşayanlar hakkında bilgiler (isim, lakap, unvan, yaş ve fizikî özellikler) ayrı ayrı tablolarla ortaya konulmaya çalıșılmıștır.

Anahtar Kelimeler: Nüfus Defteri, Medrese, Osmanlı.

\begin{abstract}
Madrassas, which is an important educational institution in the Turkish-Islamic states, also maintained its importance in the Ottoman State. In this study, it was attempted to evaluate the information related to the year of 1844 about the İstanbul madrassas population book. The notebook is briefly introduced with the available information. The information about the Istanbul madrassas (name, nickname, title, age and physical characteristics etc.) was given in tabular form on the article.
\end{abstract}

Keywords: Population Registry, Madrasa, Ottoman.

\footnotetext{
*Bu makale Aydın Bolat'ın 187 Nolu Medrese Defterine Göre İstanbul Medreseleri Nüfusu (1844) adlı yayımlanmamış Yüksek Lisans tezinden üretilmiştir.

${ }^{1}$ Tarih Öğretmeni.

${ }^{2}$ Yrd. Doç. Dr. Ondokuz Mayıs Üniversitesi Eğitim Fakültesi Ortaöğretim Sosyal Alanlar Eğitimi Bölümü Tarih Eğitimi Anabilim Dalı. pelini@omu.edu.tr
} 


\section{Giriş}

Medrese kelimesi Türkçeye Arapçadan geçmiş olup, içinde öğrencinin ilim öğrendiği yer anlamına gelmektedir ${ }^{3}$. Medreseler genellikle bir dershane ve etrafinda talebe yurtlarından (hücrelerden) meydana gelmektedir. Tesis edilen anlayış ve mali gücüne göre bunların dışında aşhane, kütüphane, hamam vs. ilave edilmektedir. Kurucusu ister bir devlet büyügü, ister başka bir şahıs olsun her medresenin bir vakfiyesi bulunmakta ve bu vakfiyede medresenin nasıl işleyeceği gösterilmektedir ${ }^{4}$. Medreseler, üç temel husus üzerinde faaliyet göstermişlerdir: Müderris yetiştirmek, devlet adamı yetiştirmek, adalet mensuplarını yetiştirmek ${ }^{5}$. Ayrıca dönemin devlet adamları eğitim, bilim ve kültür hayatını canlandırmak amacıyla başta Anadolu ve Türkistan olmak üzere çeşitli coğrafyalarda medreseler açarak eğitim ve öğretim faaliyetlerini desteklemişlerdir. Bu mirası daha sonraları Osmanlı Devleti devralmış, medreseleri tarihî seyri içerisinde en mükemmel eğitim kurumları haline getirmiştir ${ }^{6}$.

Medreseler, klasik dönem için Osmanlı Devleti'nin kurumlarına eleman yetiştiren temel eğitim kurumlarıdır ${ }^{7}$. Genel olarak üç safhada incelenebilir. Birinci safha kuruluştan XVI. asrın sonuna kadar olan klasik dönem, Osmanlı medreseleri safhasıdır. Bu dönemde akıl ve deneye dayanan ilimler, programda ismen yer almayıp vahye dayanan ilimlerin içinde okutulmuştur. İkinci safha, XIV. asırdan 1913'teki “Dârü'l-Hilâfeti'l-aliyye Medresesi” 1slahatına kadar olan dönemdir. Bu dönem, başta Kâtip Çelebi olmak üzere bazı Osmanlı mütefekkirlerinin şikâyet ettiği gibi aklî ilimlerin medreselerde okutulmasından vazgeçildiği dönem olmuştur. Üçüncü safha ise Dârü'l-Hilâfeti'l-aliyye Medresesi dönemidir ki bu dönem devrin ilim ve anlayışına göre müfredatta her şeyin açıkça görüldüğü bir dönemdir. Klasik ve gerileme dönemlerinin aksine bu dönem medreselerin programlarında naklî, aklî ve tecrübî ilimler açıkça isimleriyle yer almış hatta Rusçaya varıncaya kadar yabancı diller ders

\footnotetext{
3 Ünal TAŞKIN, “Klasik Dönem Osmanlı Eğitim Kurumları”, Uluslararası Sosyal Araştırmalar Dergisi, Volume 1/3 Spring, 2008, s. 350.

${ }^{4}$ Cahit BALTACI, "Medrese ve Elemanları”, Diyanet Dergisi, Cilt XVI. Sayı 3, Mayıs-Haziran 1977, s. 133.

${ }^{5}$ Şerife ÖZKAN, Medrese Tabirinin İlk Defa Ortaya Çıkışı, Selçuklular Zamanında Medreselerin Kuruluş Sebepleri ve Medrese Eğitimi, Yayımlanmamış Yüksek Lisans Tezi, Selçuk Üniversitesi, Sosyal Bilimler Enstitüsü, Konya 2007, s. 15.

${ }^{6}$ Mefail HIZLI, “Kuruluşundan Osmanlılara Kadar Medreseler”, Uludağ Üniversitesi İlahiyat Fakültesi Dergisi, Cilt 2, Say1 2, Bursa 1987, s. 280.

${ }^{7}$ Ramazan BALCI, "Medreselerin Islahı Konusunda Sultan II. Abdülhamid'in Hazırlattığı Bir Lahiyanın Tahlili”, Tarih Okulu Dergisi, Sayı XII, İzmir, Ocak-Nisan 2012, s. 155.
} 
programlarına girmiştir ${ }^{8}$. Osmanlı Devleti'nde ilk medrese, 1331'de İznik'te açılmıştır. Önceden manastır olan bir bina, bilgin Kayserili Davut'a medrese olarak verilmiştir. Osmanlı sultanları, daha sonraki yıllarda medrese açmak istediklerinde Konya, Kayseri ve Aksaray gibi Anadolu'nun kültür merkezlerinden ya da İslam dünyasında İran, Türkistan, Mısır, Suriye gibi yerlerden bilginler çağırmışlardır ${ }^{9}$. Osmanlı medreselerde, kuruluş itibariyle pozitif ilimlere yani aklî ilimlere ağırlık vermemiştir. Çünkü öncelikle amaçlanan İslam kültürünün yerleşmesi ve öğretilmesi olmuştur ${ }^{10}$. Devletin sınırları genişledikçe bu anlayışla birlikte, fethettiği şehirlerdeki medreselerin sayısı da giderek $\operatorname{artm}_{\text {ştır }}{ }^{11}$. Medreseler, özellikle Fatih ve Kanuni dönemlerine kadar gelişimini sürdürmüş ve bu süreçten sonra yapılan atılımlarla birlikte imparatorluğun en önemli eğitim ve öğretim kurumu haline gelmişlerdir.

Fatih Sultan Mehmet, İstanbul'u aldıktan sonra ilk iş olarak tam donanımlı büyük bir külliye vücuda getirdi. Böylece 1453 'te İstanbul Külliyesi kuruldu. Bizans Patriğinin oturmakta olduğu Havariyun Kilisesi’nin harabesi üzerine bir cami yaptırdı. $\mathrm{Bu}$ caminin iki tarafinda yüksek derslere ait 8 medrese (Sahn-1 Seman) ve bu medreselerin başlangıcı olan daha alt basamakta tahsil veren başka medreseler yaptırd ${ }^{12}$. Sahn-1 Seman medreselerinin kurulmasıyla birlikte Osmanlı Devleti sınırları içindeki medreselerin hiyerarşisi yeniden düzenlendi. Genelde Enderun mektebi hariç tutulduğunda giderek yükselen bir hiyerarşik yapıya sahip duruma geldi. Bu medreseler en alt seviyeden başlayarak sırasıyla Tecrid, Miftah, Kırklı, Hariç, Dâhil ve statüsü en yüksek olan Sahn-1 Seman medreseleri idi ${ }^{13}$.

Kanuni Sultan Süleyman zamanında, Fatih medreseleri modeli üzerine geliştirilen ve Osmanlı medrese geleneğinin zirvesi sayılan Süleymaniye medreseleri

\footnotetext{
${ }^{8}$ Cahit BALTACI, "Klasik Dönem Osmanlı İlim Müesseseleri”, İslamî Araştırmalar Dergisi, Cilt 12, Sayı 3-4, Ankara 1999, s. 260-261.

9 Halil İNALCIK, Osmanlı İmparatorluğu Klasik Çă̆ (1300-1600), Çeviren: Ruşen Sezer, YKY yayınları, İstanbul 2008, s. 175.

${ }_{10}$ M. Şerif ÇATAKOĞLU, Anadolu Selçuklu Dönemi İlmi Faaliyetleri ve Bu Faaliyetlerin Osmanlı Kuruluş Dönemi İlmi Faaliyetlerine Tesiri, Süleyman Demirel Üniversitesi Sosyal Bilimler Enstitüsü, Yüksek Lisans Tezi, Isparta 2002, s. 56-57.

11 İsmail Hakkı UZUNÇARŞILI, Osmanlı Devleti’nin İlmiye Teşkilatı, Ankara 1988, s. 1-2.

${ }^{12}$ Yücel GELIŞ̦L̇, “On Dokuzuncu Yüzyılda (Osmanlı Devleti’nin), Bağdat ve Yemen Vilayetlerinde Medreselerin Açılma Gerekçelerine İlişkin İki Belge”, Gazi Üniversitesi Gazi Eğitim Fakültesi Dergisi, Cilt 25, Sayı 2, Ankara 2005, s. 90.

${ }^{13}$ Mefail HIZLI, “Osmanlı Medreselerinde Okutulan Dersler ve Eserler”, Uludağ Üniversitesi İlâhiyat Fakültesi Dergisi, Cilt 17, Sayı 1, Bursa 2008, s. 27.
} 
kurulmuş ve medreseler altın çağını yaşamışlardır ${ }^{14}$. Teşkilat ve işleyiş olarak en yüksek seviyesine Süleymaniye Medreseleri ile ulaşmış olan bu kurumlar, diğer Osmanlı kurumlarına paralel olarak XVII. yüzyıldan itibaren bozulmaya başlamışlardır. Medreselerin bozulma sebepleri arasında en büyük faktör olarak deney, gözlem ve müspet ilimlere yeterince yer verilmemiş olması, öğretimin yöntem ve disiplin bakımından yozlaşmaya başlaması, öğretimde akli ve müspet bilimleri bırakıp yalnızca dini-şer'i bilimlerle ilgilenilmesi, yöntem bakımından aktarmacı, kitabî bir yol tutulması, Arapçaya ağırlık verilmesi, öğrencilikle ilgisi olmayan kimselerin barındırılması gibi sebepler yer almaktadır ${ }^{15}$. Osmanlının son döneminde başlayan bu gerilemeyle birlikte medreselerin yanında batı tarzı okulların açılması, eğitim ve öğretim alanında ikiliklerin meydana çıkmasına yol açmıştır. Osmanlı toplumunun dinamik yapısı içerisinde kültürel yozlaşmalara ve toplumsal çatışmalara neden olan medreseler, 3 Mart 1924 tarihinde Tevhid-i Tedrisat kanunu ile birlikte kapatılmışlardır.

Medrese nüfus defterleri, bir eğitim kurumu olan medreseler hakkında bilgi vermekle birlikte mevcut medreseler ve bunlarda yer alan öğrenci sayısı ve öğrencilerle ilgili de bir takım bilgiler vermektedir. Bu bağlamda verdiği nüfus bilgileri açısından da önemlidir. Nüfus kelimesi Arapça "nefs" kelimesinin çoğuludur, şahıs, kişi anlamına gelmektedir $^{16}$. Tarihte nüfus hizmetleri ilk olarak hane kayıtlarının tutulmasıyla başlamıştır ${ }^{17}$. Türkiye açısından nüfus hizmetleri, Osmanlı döneminde tasarlanan güçlü ve köklü geleneklere sahiptir. Osmanlılar, hazineye gelir sağlama, savunma ve fetih için asker toplama gayesi ile arazi ve nüfus sayımına ve bunlarla ilgili kayıtların tutulmasına özel bir önem vermişlerdir. Genel olarak belirli olay ve dönemlere göre yürütülen bu tahrirlerin (yazım/sayımların) başlangıcı Osmanlı Devleti’nin kuruluş yıllarına kadar gitmektedir. Bu sayım ve yazım geleneği, Cumhuriyet döneminde birebir aynı olmamakla birlikte, temel ilkeleri itibariyle aynen devam etmiştir ${ }^{18}$.

\footnotetext{
${ }^{14}$ Tuncay ZORLU, "Klasik Osmanlı Eğitim Sisteminin İki Büyük Temsilcisi: Fatih ve Süleymaniye Medreseleri”, Türkiye Araştırmaları Literatür Dergisi, Cilt 6, Sayı 12, 2008, s. 615. Bkz. Mübahat S. Kütükoğlu, XX. Asra Erişen İstanbul Medreseleri, TTK Basımevi, Ankara 2000.

15 Recai DOĞAN, "Osmanlı Eğitim Kurumları ve Eğitimde İlk Yenileşme Hareketlerinin Batılılaşma Açısından Tahlili”, Ankara Üniversitesi İlahiyat Fakültesi Dergisi, Cilt 37, Sayı 1, Ankara 1997, s. 413.

${ }^{16}$ Ferit DEVELLİOĞLU, Osmanlıca-Türkçe Ansiklopedik Lügat, Aydın Kitabevi, Ankara 1993, s.1664.

17 Adnan ÇİMEN, "Sayım, Kayıt Düzeni ve Teşkilatlanma Açısından Osmanlıda Nüfus Hizmetleri”, Gazi Üniversitesi İktisadi ve İdari Bilimler Fakültesi Dergisi, 14/3, Ankara 2012, s. 185.

${ }^{18}$ Adnan ÇİMEN, a.g.m, s. 185.
} 
Osmanlı Devleti'nde, yeni fethedilen ve tımar sistemi uygulanan topraklarda vergilendirilebilir ekonomik faaliyetlerin ve insan kaynaklarının tespiti maksadıyla, arazi ve nüfus sayımı yapılmaktaydı. Bu sayım sonuçları Tahrir adı verilen defterlere yazılır, ihtiyaç duyulması ve Padişahın değişmesiyle birlikte yenilenirdi ${ }^{19}$. "Memleket Tahriri” adı da verilen ve modern nüfus sayımı niteliğinde olmayan bu tahrirlerle arazi kayıtları yanında, devlet sınırları içinde her köy ve kasabadaki yetişkin erkek nüfus, ellerindeki toprak miktarı, tabi tutuldukları vergi mükellefiyetlerine dair rakamlar, mükelleflerin ve babalarının isimleri tek tek kaydedilirdi ${ }^{20}$. Tahrirler esnasında kaydedilen bilgiler özelliğine göre değişik defterlerde toplanırdı. Bu defterlerin başlıcaları; mufassal defter, icmal defteri ve evkaf defteri idi. Bu defterlere ek olarak kadılar tarafindan cizye ve avarız vergisi mükelleflerinin isimlerine yer veren defterler de oluşturulmuştur. Ayrıca cebelü vb. silahlı birlikler için de özel defterler düzenlenmiştir. XIX. yüzyıldaki yeni gelişmelerle birlikte sayım işlemlerinin mahiyeti de değişmeye başladı. Bu bağlamda ilk olarak 1828-29 yıllarında bir nüfus sayımı yapıldıysa da Osmanlı-Rus Savaşı nedeniyle tamamlanamadı. Bu sayımda askerî amaç, birinci sıradayd ${ }^{21}$. Bunun ardından 1830- 1831'de II. Mahmut zamanında genel bir nüfus sayımı yoluyla ülkedeki erkek nüfus belirlenmeye çalışıldı. 1830 yılı baharında Rumeli ve Anadolu taraflarında bulunan bütün eyalet, sancak ve kazalarda sayımın yapılmasına başlandı. Her ne kadar sayım gerekçesi olarak sadece halkın adil vergilendirilebilmesi esas gösterilmişse de zaman içinde elde edilen nüfus kayıtlarından yeni kurulmuş orduya asker toplamada da yararlanıldı̆̆ı görülmüştür ${ }^{22}$.

Medrese nüfus defterlerinde ise medrese ismi ve medresenin hangi mevkide olduğu kaydedilirdi. Ayrıca medresede bulunana kişilerin nereden geldikleri, sosyal statülerini gösteren unvan ve lakapları varsa not düşülürdü. Bunların dışında medreseye gelen kişilerin fizikî özellikleri hakkında bilgiler verilirdi. Örneğin kişinin boy, sakal ve bıyık durumu ifade edilirdi. Yine medreseye kayıtlı kişilerin yaşları da kaydedilirdi. Varsa kişilerin nakil durumları, hangi aylarda geldikleri ve dönüş yaptıkları şeklinde

\footnotetext{
${ }^{19}$ Enver ÇAKAR, “Tahrir Defterlerine Göre XVI. Yüzyılda Humus Şehri”, Fırat Üniversitesi Sosyal Bilimler Dergisi, Cilt 13, Sayı 2, Elazı̆̆ 2003, s. 377.

20 Sedat BİNGÖL, "İstanbul'da 1829 Nüfus Sayımı ve Bazı Mahallelerin Müslüman Nüfusu Üzerine Bir İnceleme", Ankara Üniversitesi Dil ve Tarih-Coğrafya Fakültesi Tarih Bölümü Tarih Araştırmaları Dergisi, Cilt 23 Say1 36, s. 44.

${ }^{21}$ Sedat Bingöl, 1829 İstanbul Nüfus Sayımı ve Tophane Kasabası, Eskişehir 2004, s. VII.

${ }^{22}$ Enver Ziya Karal, Osmanlı İmparatorluğunda İlk Nüfus Sayımı 1831, Ankara 1997, s. VII.
} 
bilgiler de mevcuttu ${ }^{23}$. Bu defterler incelendikçe, Osmanlı müesseselerine olan katkıları daha net bir şekilde ortaya çıkacaktır.

\section{Nolu Medrese Nüfus Defterinde Yer Alan İstanbul Medreseleri Ve}

\section{Özellikleri}

İstanbul medreseleri ile ilgili çalışmalar, 1974 yılında Konya'da Koyunoğlu Kütüphanesindeki araştırmalar neticesinde başlamıştır. 1869 tarihli İstanbul medreseleri ile ilgili liste, devrin şeyhülislamının emriyle hazırlanmış ve neşredilmiştir. Bu belgeler 1şı̆̆ında Mübahat Kütükoğlu, “1869'da Faal İstanbul Medreseleri” adlı makalesini kaleme almıştır. Burada İstanbul'da bulunan 166 faal medresenin ayrı ayrı ve toplamdaki nüfusu, kaç müderrisin bulunduğu, her bir dersi kaç talebenin takip ettiği ve bu tarihte medreselerde hangi derslerin okutulmakta olduğu görülmektedir. $\mathrm{Bu}$ çalışmayı, 1978 tarihli "Dârü'l-Hilâfeti'l Aliyye Medresesi ve Kuruluş Aşamasında İstanbul Medreseleri” adlı makale takip etmiştir. Daha sonra bu iki çalışmadan hareketle "XX. Asra Erişen İstanbul Medreseleri” adlı eser yayımlanmıştır. Yapılan araştırmalar neticesinde, 1844 yılına ait İstanbul medreseleri hakkında herhangi bir araştırma yapılmadığı tespit edilmiştir. Başbakanlık Osmanlı Arşivi’nde yapılan katalog taraması neticesinde, 1844 y1lı İstanbul medreselerine ait 16 adet nüfus defteri tespit edilmiştir.

İncelenen nüfus defteri ebrusuz ve ciltli, 20.5 x 52 ebadındadır. Numaralandırma usulü varak olmayıp sayfa usulüne göre numaralandırma yapılmıştır. Ayrıca numaralandırma sisteminde Arabî rakamlar kullanılmamıştır. Toplam sayfa numarası bilgi formunda 194 olarak belirtilmektedir. Numaralı boş sayfalar ise şu şekildedir: 3-4, 10-12, 23-28, 35-38, 46-48, 61-62, 67-68, 85-86, 89-96, 99-100, 103-104, 112-116, 123-124, 136-138, 149-150, 161-162, 167-168, 172-175, 177-180, 183-184, 191-192, 194.

Defterde genellikle bir sayfada 32 öğrenci bulunmakta, bir satırda çoğunlukla dört kişiye ait bilgiler yer almaktadır. Kişilerin fizikî özellikleri ile birlikte isim ve lakabı, baba adı, memleketi, yaşı, kaldığı odanın durumu ve değişik tarihlerde başta cer olmak üzere gitmiş olduğu ve geldiği yerler belirtilmektedir.

Defterde 37 adet medrese mevcuttur. Medrese isimlerinin hemen altında medrese sıra numarası Arabî rakamlarla verilmiştir. 46 numaralı medrese olan Medresei Derûn Hâni Hilâlci der-Süleymaniye medresesinde 59 numaralı sıra ile 116 numaralı

${ }^{23}$ BOA, NFS. d.187. 
sıra arasında bulunan sayfaların olmadığı görülmektedir. Dolayısıyla 57 kişiye ait bilgilere ulaşılamamıştır. Medreselerde talebenin yanında bevvab, hattat, mülazım ve müderrisler de kaydedilmiştir. Bazı kişilerin çocuğuyla bazı kişilerin de kardeşiyle birlikte kaldığı tespit edilmiştir. Aralarında akrabalık bağı bulunan bu kişiler genellikle aynı odayı paylaşmaktadırlar.

İncelenen defterde medreselerin genelinde 1.776 kişi bulunmaktadır. Genel itibariyle 122 farklı isim kullanılmıştır. Bunlardan 105 kişi tek isim, 44 kişi çift isim kullanmıştır. En çok kullanılan tek isimler; Ahmet, Ali, Hasan, Hüseyin, İsmail, Mustafa, Mehmet, Osman, Salih'tir ${ }^{24}$. En çok kullanılan çift isimler ise; Mehmet Ali, Mehmet Akif, Mehmet Emin, Mehmet Salih'tir ${ }^{25}$.

1.692 kişinin geldikleri yerler belirtilmiş, 84 kişinin memleketleriyle ilgili bilgi verilmemiştir. İncelenen medreselerde yer alan kişiler geldikleri yerler itibarıyla Anadolu, Balkanlar ve diğeri (Kafkasya, Arap coğrafyası) olarak sınıflandırılmıştır. En çok geldikleri yerler Tablo 1'de verilmiştir. Buna göre:

Tablo 1: Medreselere Kayıtlı Kişilerin Geldikleri Memleketler

\begin{tabular}{|c|c|c|c|c|c|c|c|}
\hline \multicolumn{2}{|c|}{ Andolu } & \multicolumn{2}{|c|}{ Anadolu } & \multicolumn{2}{|c|}{ Balkan } & \multicolumn{2}{|c|}{ Diğer } \\
\hline Yer & 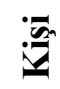 & Yer & 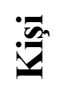 & Yer & 氛 & Yer & 芸 \\
\hline Adana & 2 & Kadiriye & 2 & Aydos & 2 & Ahıska & 10 \\
\hline Adapazarı & $\begin{array}{l}1 \\
4\end{array}$ & Kandıra & 5 & Banja Luka & 2 & Beslan & 2 \\
\hline Akçaşehir & 6 & Kangal & 2 & Belgrad & 2 & Beyrut & 1 \\
\hline Akhisar & $\begin{array}{l}1 \\
3\end{array}$ & Karaağaç & 9 & Berkofça & 7 & Cidde & 1 \\
\hline
\end{tabular}

\footnotetext{
${ }^{24}$ Abbas, Abdi, Abdulgaffur, Abdullah, Abdurrahman, Abdurrezzak, Abdülaziz, Abdülferid, Abdülhalim, Abdülhamid, Abdülkadir, Abdülkerim, Abdüllatif, Abdülmuttalib, Abdürrahim, Adem, Ali, Ahmed, Arif, Bahaeddin, Bediürahman, Bekir, Bayezid, Beytullah, Bilal, Cafer, Derviş, Durmuş, Ebubekir, Emrah, Emrullah, Esad, Edhem, Eyyüb, Fazlı, Ferhad, Ferid, Fevzi, Feyzullah, Halid, Halil, Halim, Hamid, Hamza, Hasan, Haşim, Hayreddin, Hayrullah, Hıfsı, Hidayet, Hikmetullah, Himmet, Hüseyin, İbrahim, İdris, İsa, İshak, İsmail, Kasım, Kerim, Lütfullah, Mahmud, Mecidullah, Musa, Mustafa, Müfid, Münir, Naim, Nasuh, Nazmi, Necib, Numan, Nurettin, Nuri, Nusreddin, Osman, Ömer, Ramazan, Raşid, Receb, Rüstem, Rüşdü, Sadık, Sadullah, Salih, Selim, Selman, Sina, Süleyman, Şaban, Şakir, Şerif, Şükrü, Tahir, Tuti, Vasfi, Veli, Veliddin, Veysi, Yahya, Yakub, Yusuf, Zekeriya, Zeynelabidin, Zühdü.

${ }^{25}$ Abdullah Reşid, Ahmet Aziz, Ahmed Habib, Ahmed Latif, Ahmed Nuri, Ahmed Şakir, Ali Hilmi, Ali Kadir, Ali Osman, Ali Ruşen, Ali Seydi, Eyyüb Arif, Halil İbrahim, Halil Rıfat, Halil Zühdü, Hüseyin Hüsnü, Hüseyin Reşid, Hüseyin Şükrü, İbrahim Edhem, İbrahim Nuri, Mehmed Ali, Mehmed Arif, Mehmed Akif, Mehmed Emin, Mehmed Haşim, Mehmed Hilmi, Mehmed Muhsin, Mehmed Muzaffer, Mehmed Niyazi, Mehmed Numan, Mehmed Nuri, Mehmed Raşid, Mehmed Rüşdü, Mehmed Sadık, Mehmed Said, Mehmed Salim, Mehmed Salih, Mehmed Şakir, Mehmed Şükrü, Mehmed Tahir, Mehmed Tevfik, Mehmed Veli, Mustafa Tevfik, Süleyman Necip.
} 


\begin{tabular}{|c|c|c|c|c|c|c|c|}
\hline Aksaray & 6 & Karacabey & 2 & Berzek & 2 & Dağıstan & 2 \\
\hline Akşehir & $\begin{array}{l}1 \\
7\end{array}$ & Karahisar & $\begin{array}{l}1 \\
4\end{array}$ & Bosna & $\begin{array}{l}9 \\
8\end{array}$ & Halepçe & 2 \\
\hline Alanya & 5 & Karaman & 4 & Cuma-i Atik & 2 & Hicaz & 2 \\
\hline Alaplı & 4 & Karamürsel & 5 & Demirhisar & 2 & Kirman & 1 \\
\hline Amasya & $\begin{array}{l}1 \\
1\end{array}$ & Karasu & $\begin{array}{l}1 \\
2\end{array}$ & Drama & 9 & Lazkiye & 1 \\
\hline Ankara & $\begin{array}{l}1 \\
2 \\
\end{array}$ & Karıpazarı & 2 & Elbasan & 2 & Lefke & 2 \\
\hline Antalya & 2 & Kars & 3 & Filibe & $\begin{array}{l}1 \\
4 \\
\end{array}$ & Kefe & 3 \\
\hline Ayaş & $\begin{array}{l}1 \\
0\end{array}$ & Kastamonu & $\begin{array}{l}8 \\
4\end{array}$ & Gümülcine & $\begin{array}{l}1 \\
3\end{array}$ & & \\
\hline Aydın & 8 & Kayseri & 5 & $\begin{array}{l}\text { Hacioğlu } \\
\text { Pazarcık }\end{array}$ & 6 & & \\
\hline Ayvacık & 9 & Kemah & $\begin{array}{l}1 \\
2\end{array}$ & İstanköy & 2 & & \\
\hline Bafra & 5 & Keşan & 2 & Kalkandelen & 3 & & \\
\hline Bandırma & 2 & Kırkağaç & 2 & Karinabad & 4 & & \\
\hline Bartın & 6 & Kırşehir & 3 & Kavala & 5 & & \\
\hline Bayburt & 2 & Koçhisar & 3 & Kazanlık & 4 & & \\
\hline Bayramiç & 4 & Konya & $\begin{array}{l}2 \\
9\end{array}$ & Köstence & 5 & & \\
\hline Bayramlı & 2 & Kozluca & $\begin{array}{l}1 \\
3 \\
\end{array}$ & Manastır & 5 & & \\
\hline Bergama & 4 & Kuyucak & $\begin{array}{l}1 \\
0\end{array}$ & Mankalya & 2 & & \\
\hline Beydere & 2 & Küre & 4 & Midilli & 3 & & \\
\hline Beyşehir & $\begin{array}{l}2 \\
1\end{array}$ & Kütahya & $\begin{array}{l}1 \\
6\end{array}$ & Nevrekop & 2 & & \\
\hline Beypazarı & 2 & Lapseki & 8 & Niğbolu & 2 & & \\
\hline Biga & $\begin{array}{l}1 \\
3\end{array}$ & Livane & 4 & Ohri & 2 & & \\
\hline Bilecik & $\begin{array}{l}1 \\
8\end{array}$ & Malatya & 5 & Osmanpazarı & 2 & & \\
\hline Bodrum & 8 & Manisa & 3 & Palanca & 2 & & \\
\hline Bolu & $\begin{array}{l}2 \\
5 \\
\end{array}$ & Mendirek & 7 & Piriştine & 2 & & \\
\hline Bursa & 2 & Mihaliç & 5 & Pravadi & 2 & & \\
\hline Büyükçekmece & 2 & Milas & 2 & Rodos & 2 & & \\
\hline Çankırı & 4 & Nevşehir & & Rusçuk & & & \\
\hline
\end{tabular}




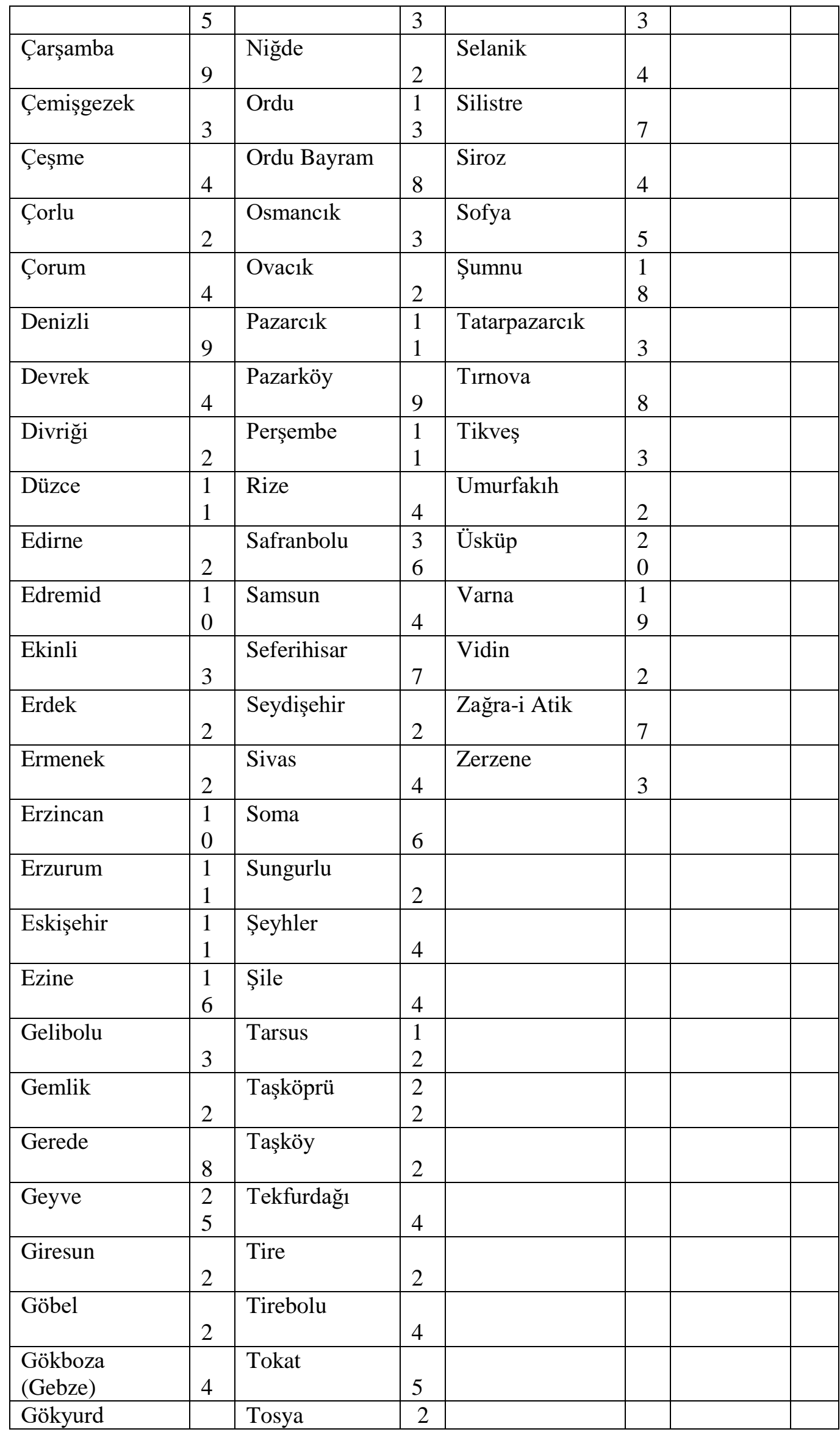




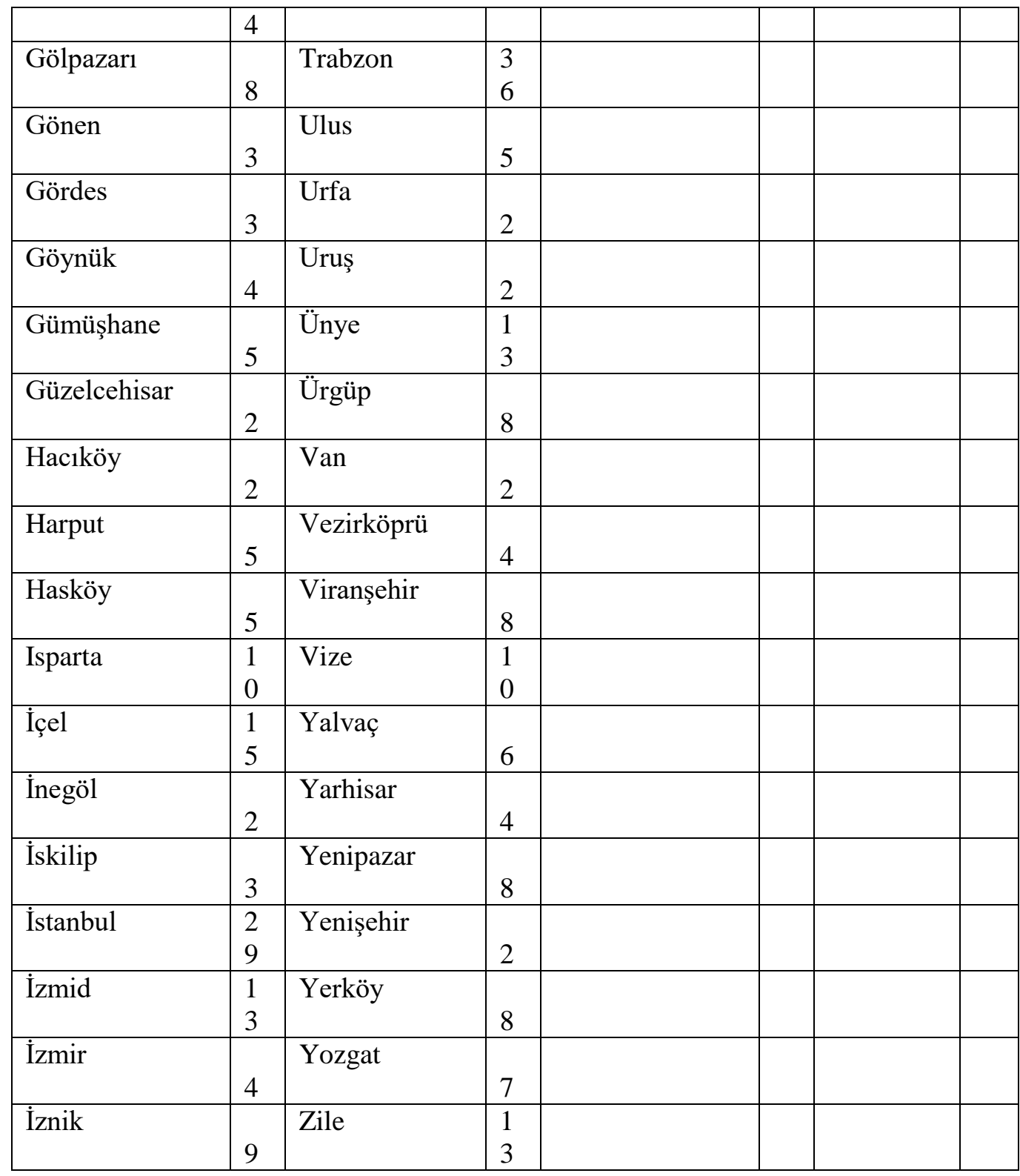

\section{Süleymaniye Dâr-ül Hadis Medresesi}

Medrese Haliç tarafındadır. 1792 sayımında medresede biri müderris 45 kişi kalmaktadır ${ }^{26} .1844$ yılında yapılan sayımda toplamda 75 kişi bulunmaktadır. Bunlarda 22 farklı ismin kullandığ 1 görülmektedir. En fazla kullanılan isimler Mehmet, Ahmet, Mustafa ve İsmail’dir. Ayrıca 10 farklı çift isim kullanılmıştır. 6 kişi Kastamonulu, 6 kişi Bigalı, 5 kişi Beyşehirli, 4 kişi Devrekli 4 kişi ise Perşembelidir. Medresenin yaş ortalaması 25'tir. En yaşlı kişi 75 yaşında, en küçüğü ise 10 yaşındadır. Fizikî evsaf olarak 6 kişi kısa boylu, 39 kişi orta, 9 kişi de uzun boyludur. Medresede toplamda 17

26 Mustafa Göleç-Fatih Güldal, İstanbul'un 100 Mektebi ve Medresesi, İstanbul'un Yüzleri Serisi-50, İstanbul Büyükşehir Belediyesi, İstanbul 2012, s.159. Bkz. Mübahat S. Kütükoğlu, XX. Asra Erişen İstanbul Medreseleri, TTK Basımevi, Ankara 2000. 
oda bulunmaktadır. Bunların bir kısmında iki kişi bir kısmında ise tek kişi kalmaktadır. 9 numaralı oda boş haldedir. Bir kişi mülazımdır. 1914'te 45 talebenin okuduğu medresede aynı tarihli teftiş raporuna göre 30 talebe ikamet etmektedir. Günümüze ulaşan medrese özgün görünümünü kaybetmiştir. Aziziye Sosyal Dayanışma Kültür ve Eğitim Vakfı'na tahsis edilmiştir ${ }^{27}$.

Tablo 1: Medrese-i Ahşab Der-Derûn-1 Camii-i Süleymaniye’ye Kayıtlı Olan Kişilerin Genel Özellikleri

\begin{tabular}{|c|c|c|c|c|c|c|c|c|c|c|c|c|c|c|c|c|c|c|c|c|}
\hline \multicolumn{7}{|c|}{ Yaş Aralığı } & \multicolumn{5}{|c|}{ Boy } & \multicolumn{9}{|c|}{ Memleket } \\
\hline \multicolumn{2}{|c|}{$0-14$} & \multicolumn{2}{|c|}{$15-39$} & \multicolumn{2}{|c|}{$\begin{array}{ll}40 & \text { ve } \\
+ & \\
\end{array}$} & & Kisa & \multicolumn{2}{|c|}{ Orta } & \multicolumn{2}{|c|}{$\begin{array}{l}\text { Uzu } \\
\text { n }\end{array}$} & \multicolumn{3}{|c|}{$\begin{array}{l}\text { Anadol } \\
\text { u }\end{array}$} & \multicolumn{3}{|c|}{$\begin{array}{l}\text { Balkanla } \\
\mathbf{r}\end{array}$} & \multicolumn{3}{|c|}{ Diğer } \\
\hline \multicolumn{2}{|c|}{10 kişi } & \multicolumn{2}{|c|}{58 kişi } & \multicolumn{2}{|c|}{7 kişi } & \multicolumn{3}{|c|}{\begin{tabular}{|l|}
6 \\
kişi \\
\end{tabular}} & 39 kişi & \multicolumn{2}{|c|}{$\begin{array}{l}9 \\
\text { kişi }\end{array}$} & \multicolumn{3}{|c|}{60 kişi } & \multicolumn{3}{|c|}{3 kişi } & \multicolumn{3}{|c|}{11 kişi } \\
\hline \multicolumn{10}{|c|}{ Sakal-Bıyık } & \multicolumn{11}{|c|}{ İsim } \\
\hline 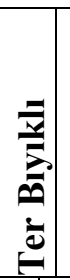 & $\frac{0}{\frac{0}{\pi}}$ & 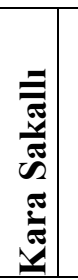 & 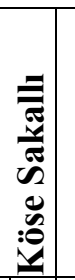 & 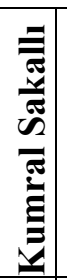 & 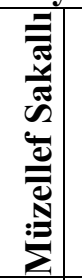 & 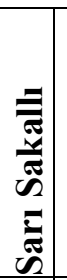 & 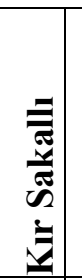 & 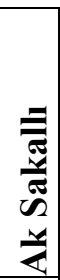 & 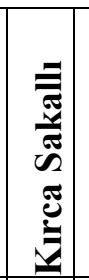 & 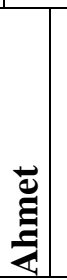 & 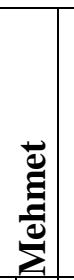 & 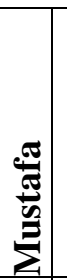 & 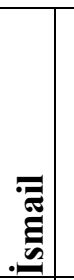 & $\ddot{z}$ & 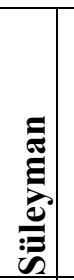 & 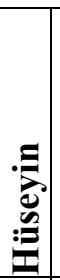 & 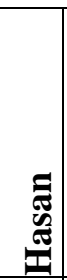 & قِ & 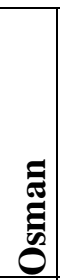 & $\frac{\pi}{\pi}$ \\
\hline \begin{tabular}{l|l}
4 & 1 \\
\end{tabular} & 19 & 15 & 1 & 9 & 1 & 6 & 1 & 1 & 1 & 10 & & & 6 & 5 & 5 & 5 & 4 & 4 & 3 & 2 \\
\hline
\end{tabular}

\section{Ahşab Medrese}

1844 y1lı sayımında deftere12 kişi kayıtlıdır. 6 numaralı sıra boştur. 10 farklı isim kullanılmıştır. Mehmet ve İsmail en fazla kullanılan isimlerdir. Medresenin yaş ortalaması 20'dir. En yaşlı kişi 31, en küçüğü ise 11 yaşındadır. Fizikî özellik olarak 1 kişi kısa, 6 kişi orta, 1 kişi de uzun boyludur. Medresede 2 oda mevcuttur. Medresedeki kişiler genellikle Karadeniz bölgesinden gelmişlerdir. Trabzon, Perşembe, Amasya, Safranbolu'dan gelen insanlar vardir.

Tablo 2: Medrese-i Ahşab Der-Derûn-1 Camii-i Süleymaniye’ye Kayıtlı Olan Kişilerin Genel Özellikleri

\begin{tabular}{|c|c|c|c|c|c|c|c|c|}
\hline \multicolumn{3}{|c|}{ Yaş Aralı̆̆ } & \multicolumn{3}{|c|}{ Boy } & \multicolumn{3}{|c|}{ Memleket } \\
\hline $0-14$ & 15-39 & $\begin{array}{ll}40 \text { ve } \\
+\end{array}$ & Kisa & Orta & Uzun & Anadolu & $\begin{array}{l}\text { Balkanla } \\
\mathbf{r}\end{array}$ & $\begin{array}{l}\text { Diğe } \\
\text { r }\end{array}$ \\
\hline $\begin{array}{l}3 \\
\text { kiși }\end{array}$ & 9 kişi & ---- & 1 kişi & 6 kişi & 1 kişi & 9 kişi & 1 kişi & 2 kişi \\
\hline
\end{tabular}

${ }^{27}$ Mustafa Göleç-Fatih Güldal, a.g.e, s.159. 


\begin{tabular}{|c|c|c|c|c|c|c|c|c|c|c|c|c|c|c|c|c|}
\hline \multicolumn{7}{|c|}{ Sakal-Bıyık } & \multicolumn{10}{|c|}{ İsim } \\
\hline 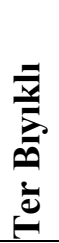 & $\frac{0}{\frac{0}{\pi}}$ & 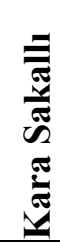 & 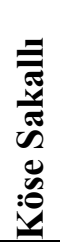 & 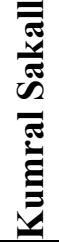 & 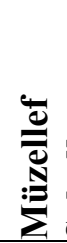 & 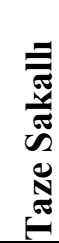 & 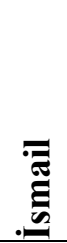 & 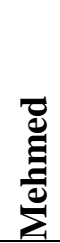 & $\begin{array}{l}\frac{\pi}{\mathbb{J}} \\
\stackrel{\mathscr{S}}{\Xi} \\
\sum\end{array}$ & $\stackrel{\vec{巳}}{\stackrel{\Xi}{\Xi}}$ & $\gtreqless$ & 嘅 & 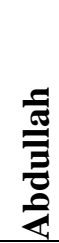 & : & 嫣 & 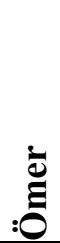 \\
\hline 1 & 4 & 2 & 1 & 2 & 1 & 1 & 2 & 2 & 1 & 1 & 1 & 1 & 1 & 1 & 1 & 1 \\
\hline
\end{tabular}

\section{Süleymaniye Mülâzımlar Medresesi}

Haliç tarafındaki medreselerin alt tarafındadır. Medrese iki katlıdır ve 20 odası bulunmaktadır. Bunların ikisi fevkânî, 18 ise tahtanîdir ${ }^{28} .1844$ yılı sayımına göre 72 kişi deftere kayıtlıdır. 26 farklı isim kullanılmıştır. Mehmet, Mustafa ve Ahmet en fazla kullanılan isimlerdir. 7 kişi çift isim kullanmaktadır. Abdullah, Yakub, Bekir, Edhem gibi isimlerde vardır. 6 kişi Trabzonlu, 3 kişi Bigalıdır. Medresenin yaş ortalaması 22'dir. En yaşlı kişi 43, en küçük kişi 12 yaşındadır. Fizikî evsaf olarak 3 kişi kısa, 41 kişi orta, 8 kişide uzun boyludur. Bir kişi mülazım olarak bulunmaktadır. 1914 tarihli teftiş raporuna göre 30 talebe ikamet edebilir.

Tablo 3: Medrese-i Mülâzımlar der-Süleymaniye'ye Kayıtlı Olan Kişilerin Genel Özellikleri

\begin{tabular}{|c|c|c|c|c|c|c|c|c|c|c|c|c|c|c|c|c|c|c|}
\hline \multicolumn{6}{|c|}{ Yaș Aralı̆̆ı } & \multicolumn{6}{|c|}{ Boy } & \multicolumn{7}{|c|}{ Memleket } \\
\hline \multicolumn{2}{|c|}{$0-14$} & \multicolumn{2}{|c|}{$15-39$} & \multicolumn{2}{|c|}{$\begin{array}{ll}40 & \text { ve } \\
+ & \\
\end{array}$} & \multicolumn{2}{|c|}{ Kisa } & \multicolumn{2}{|c|}{ Orta } & \multicolumn{2}{|c|}{ Uzun } & \multicolumn{2}{|c|}{$\begin{array}{l}\text { Anadol } \\
\text { u }\end{array}$} & \multicolumn{3}{|c|}{$\begin{array}{l}\text { Balkanla } \\
\mathbf{r}\end{array}$} & \multicolumn{2}{|c|}{ Diğer } \\
\hline \multicolumn{2}{|c|}{8 kişi } & \multicolumn{2}{|c|}{$\begin{array}{l}61 \\
\text { kişi }\end{array}$} & \multicolumn{2}{|c|}{3 kişi } & \multicolumn{2}{|c|}{3 kişi } & \multicolumn{2}{|c|}{$\begin{array}{c}41 \\
\text { kişi }\end{array}$} & \multicolumn{2}{|c|}{8 kişi } & \multicolumn{2}{|c|}{49 kişi } & \multicolumn{3}{|c|}{4 kişi } & \multicolumn{2}{|l|}{$\begin{array}{c}19 \\
\text { kişi }\end{array}$} \\
\hline \multicolumn{10}{|c|}{ Sakal-Bıyık } & \multicolumn{9}{|c|}{ İsim } \\
\hline 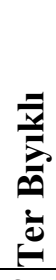 & $\frac{0}{6}$ & 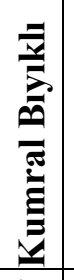 & 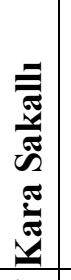 & 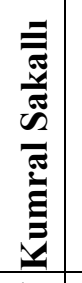 & 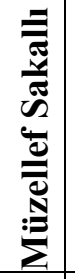 & 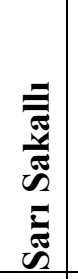 & 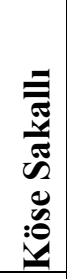 & 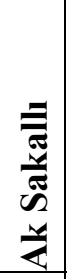 & 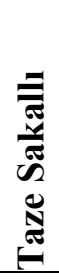 & 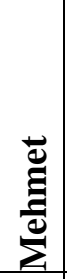 & 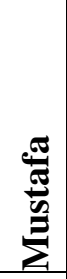 & $\underset{\dot{\Xi}}{\vec{\Xi}}$ & 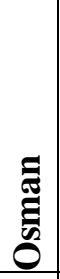 & 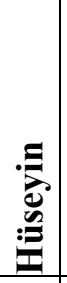 & 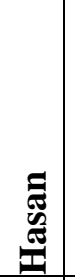 & 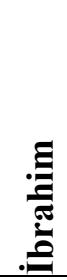 & ప̈ & 플 \\
\hline 3 & $\begin{array}{l}2 \\
1\end{array}$ & 1 & $\begin{array}{l}1 \\
1\end{array}$ & $\begin{array}{l}1 \\
6\end{array}$ & 5 & 7 & 3 & 1 & 1 & $\begin{array}{l}1 \\
8\end{array}$ & 7 & 7 & 5 & 4 & 3 & 3 & 3 & 2 \\
\hline
\end{tabular}

\footnotetext{
${ }^{28}$ Mustafa Göleç-Fatih Güldal, a.g.e, s.158-159. Bkz. Mürşide Baykal, Süleymaniye Külliyesi, İ.Ü. Edebiyat Fakültesi Sanat Tarihi Mezuniyet Tezi, İstanbul 1952.
} 


\section{Süleymaniye Evvel Medresesi}

Süleymaniye Camii’nin tam karşısında yer almaktadır. 1844 yılı sayımında 105 kişi vardır. 28 farklı isim kullanılmıştır. 5 kişi çift isimlidir. Medresenin yaş ortalaması 23 'tür. En yaşlı kişi 60, en küçük kişi ise 10 yaşındadır. Fizikî evsaf olarak 8 kişi kısa, 38 kişi orta, 28 kişi uzun boyludur. Medresede 20 oda vardır. 1, 3, 14 numaralı odalar boştur. Bir kişi mülazımdır. 10 kişi Çankırılı, 9 kişi Kastamonulu, 5 kişi Adapazarlıdır. Günümüzde Süleymaniye Kütüphanesi olarak hizmet vermektedir. Zemin kat ise ticarî işler için kullanılmaktadır ${ }^{29}$.

Tablo: 4 Medrese-i Evvel-i der-Süleymaniye’ye Kayıtlı Olan Kişilerin Genel Özellikleri

\begin{tabular}{|c|c|c|c|c|c|c|c|c|c|c|c|c|c|c|c|c|c|c|}
\hline \multicolumn{6}{|c|}{ Yaş Aralı̆̆ı } & \multicolumn{6}{|c|}{ Boy } & \multicolumn{7}{|c|}{ Memleket } \\
\hline \multicolumn{2}{|c|}{$0-14$} & \multicolumn{2}{|c|}{ 15-39 } & \multicolumn{2}{|c|}{$\begin{array}{ll}40 & \text { ve } \\
+ & \end{array}$} & \multicolumn{2}{|c|}{ Kisa } & \multicolumn{2}{|c|}{ Orta } & \multicolumn{2}{|c|}{ Uzun } & \multicolumn{2}{|c|}{$\begin{array}{l}\text { Anadol } \\
\text { u }\end{array}$} & \multicolumn{3}{|c|}{\begin{tabular}{|l} 
Balkanla \\
$\mathbf{r}$
\end{tabular}} & \multicolumn{2}{|c|}{ Diğer } \\
\hline \multicolumn{2}{|c|}{8 kişi } & \multicolumn{2}{|c|}{92 kişi } & \multicolumn{2}{|c|}{5 kişi } & \multicolumn{2}{|c|}{8 kişi } & \multicolumn{2}{|c|}{38 kişi } & \multicolumn{2}{|c|}{28 kişi } & \multicolumn{2}{|c|}{75 kişi } & \multicolumn{3}{|c|}{11 kişi } & \multicolumn{2}{|c|}{19 kişi } \\
\hline \multicolumn{10}{|c|}{ Sakal-Bıylk } & \multicolumn{9}{|c|}{ İsim } \\
\hline 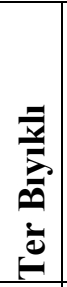 & 音 & 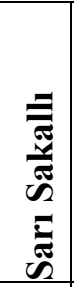 & 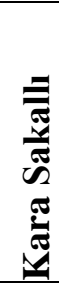 & 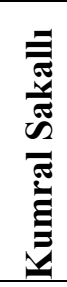 & 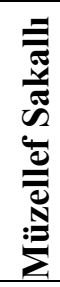 & 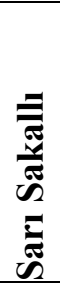 & 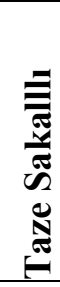 & 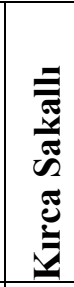 & $\frac{7}{2}$ & 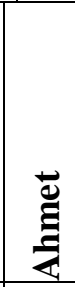 & ¿ & 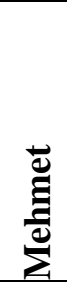 & 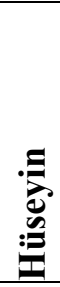 & 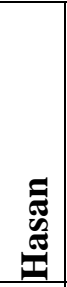 & 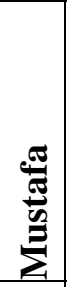 & 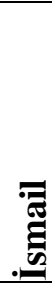 & 营 & قِ \\
\hline 3 & $\begin{array}{l}3 \\
5\end{array}$ & $\begin{array}{l}1 \\
7\end{array}$ & $\begin{array}{l}1 \\
6\end{array}$ & $\begin{array}{l}1 \\
4\end{array}$ & 9 & 1 & 1 & 1 & 1 & $\begin{array}{l}1 \\
4\end{array}$ & $\begin{array}{l}1 \\
4\end{array}$ & $\begin{array}{l}1 \\
4\end{array}$ & 8 & 7 & 6 & 5 & 5 & 4 \\
\hline
\end{tabular}

\section{Süleymaniye Sâniye Medresesi}

Süleymaniye Camii'nin tam karşısındadır. 1844 yılı sayımına göre 102 kişi vardır. 32 farklı isim kullanılmıştır. Mehmet, Mustafa ve Ali en fazla kullanılan isimlerdir. 14 kişi çift isim kullanmıştır. 5 kişi Ünyeli, 5 kişi Boluludur. Medresenin yaş ortalaması 23'tür. En büyük yaş 55, en küçük ise 8'dir. Fizikî evsaf olarak 8 kişi kısa, 51 kişi orta, 9 kişi uzun boyludur. Medresede 23 oda vardır. 8, 12, 13, 15, 19, 20 numaralı odalar boştur. Bir kişi mülazımdır. 1914 raporuna göre 14 baraka ile 20 odaya sahiptir. 20 kişi ikamet edebilirr ${ }^{30}$.

\footnotetext{
${ }^{29}$ Mustafa Göleç-Fatih Güldal, a.g.e, s.155.

30 Mübahat Kütükoğlu, "Darü'l-Hilafeti'l-Aliyye Medreseleri ve Kuruluş Arefesinde İstanbul Medreseleri”, ITED, İstanbul 1978, s.59.
} 
Tablo 5: Medrese-i Sâniye-i der-Süleymaniye’ye Kayıtlı Olan Kişilerin Genel Özellikleri

\begin{tabular}{|c|c|c|c|c|c|c|c|c|c|c|c|c|c|c|c|c|c|c|}
\hline \multicolumn{6}{|c|}{ Yaş Aralığı } & \multicolumn{6}{|c|}{ Bоу } & \multicolumn{7}{|c|}{ Memleket } \\
\hline \multicolumn{2}{|c|}{$0-14$} & \multicolumn{2}{|c|}{$15-39$} & \multicolumn{2}{|c|}{$\begin{array}{l}40 \text { ve } \\
+\quad \\
\end{array}$} & \multicolumn{2}{|c|}{ Kisa } & \multicolumn{2}{|c|}{ Orta } & \multicolumn{2}{|c|}{ Uzun } & \multicolumn{2}{|c|}{$\begin{array}{l}\text { Anadol } \\
\text { u }\end{array}$} & \multicolumn{3}{|c|}{\begin{tabular}{|l} 
Balkanla \\
$\mathbf{r}$
\end{tabular}} & \multicolumn{2}{|c|}{ Diğer } \\
\hline \multicolumn{2}{|c|}{11 kişi } & \multicolumn{2}{|c|}{87 kişi } & \multicolumn{2}{|c|}{4 kişi } & & \multicolumn{2}{|c|}{51 kişi } & \multicolumn{2}{|c|}{9 kişi } & \multicolumn{2}{|c|}{88 kişi } & \multicolumn{3}{|c|}{6 kişi } & \multicolumn{2}{|c|}{8 kişi } \\
\hline \multicolumn{9}{|c|}{ Sakal-Bıyık } & \multicolumn{10}{|c|}{ İsim } \\
\hline 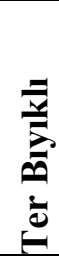 & $\frac{0}{2}$ & 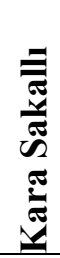 & 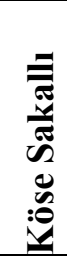 & 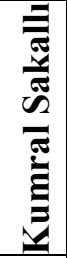 & 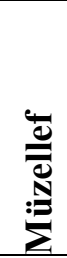 & 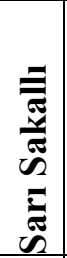 & 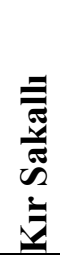 & 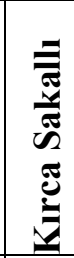 & 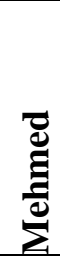 & 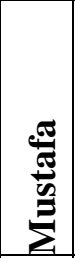 & 言 & 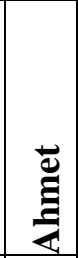 & 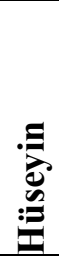 & 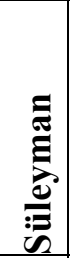 & 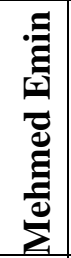 & 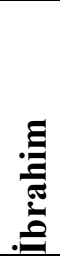 & 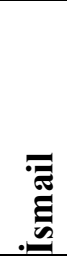 & $\begin{array}{l}\tilde{E} \\
\text { है } \\
\text { है }\end{array}$ \\
\hline 1 & $\begin{array}{l}2 \\
9\end{array}$ & $\begin{array}{l}1 \\
9\end{array}$ & 2 & $\begin{array}{l}1 \\
9\end{array}$ & 8 & 5 & 1 & 2 & $\begin{array}{l}1 \\
5\end{array}$ & $\begin{array}{l}\mathbf{1} \\
\mathbf{0}\end{array}$ & 9 & 7 & 7 & 6 & 5 & 4 & 4 & 4 \\
\hline
\end{tabular}

\section{Süleymaniye Sâlise Medresesi}

Süleymaniye Mahallesi Mimar Sinan Caddesindedir. 1844 sayımına göre 123 kişi bulunmaktadır. 34 farklı isim kullanılmıştır. Mehmet, Ahmet ve Mustafa en fazla kullanılan isimlerdir. Medresenin yaş ortalaması 23'tür. En yaşlı olan kişi 67, en küçük olan ise 10 yaşındadır. Fizikî özellik olarak 10 kişi kısa, 56 kişi orta, 20 kişi uzun boyludur. Medresede 23 oda vardır. 10 numaralı oda boştur. 1 kişi mülazımdır. 12 kişi Kastamonulu, 7 kişi Erzincanlı, 6 kişi Çankırılı, 6 kişi Kemahlı, 5 kişi Karasuludur.

Tablo 6: Medrese-i Sâlise-i der-Süleymaniye’ye Kayıtlı Olan Kişilerin Genel Özellikleri

\begin{tabular}{|c|c|c|c|c|c|c|c|c|c|c|c|c|c|c|c|c|c|c|}
\hline \multicolumn{6}{|c|}{ Yaş Aralığı } & \multicolumn{6}{|c|}{ Boy } & \multicolumn{7}{|c|}{ Memleket } \\
\hline \multicolumn{2}{|c|}{$0-14$} & \multicolumn{2}{|c|}{$15-39$} & \multicolumn{2}{|c|}{$\begin{array}{ll}40 & \text { ve } \\
+ & \end{array}$} & \multicolumn{2}{|c|}{ Kisa } & \multicolumn{2}{|c|}{ Orta } & \multicolumn{2}{|c|}{ Uzun } & \multicolumn{2}{|c|}{$\begin{array}{l}\text { Anadol } \\
\text { u }\end{array}$} & \multicolumn{3}{|c|}{\begin{tabular}{|l|} 
Balkanla \\
$\mathbf{r}$
\end{tabular}} & \multicolumn{2}{|c|}{ Diğger } \\
\hline \multicolumn{2}{|c|}{14 kişi } & \multicolumn{2}{|c|}{98 kişi } & \multicolumn{2}{|c|}{11 kişi } & \multicolumn{2}{|c|}{10 kişi } & \multicolumn{2}{|c|}{56 kişi } & \multicolumn{2}{|c|}{20 kişi } & \multicolumn{2}{|c|}{89 kişi } & \multicolumn{3}{|c|}{16 kişi } & \multicolumn{2}{|c|}{$\begin{array}{c}16 \\
\text { kişi }\end{array}$} \\
\hline \multicolumn{10}{|c|}{ Sakal-Bıyık } & \multicolumn{9}{|c|}{ İsim } \\
\hline 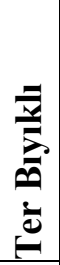 & $\frac{0}{\frac{\pi}{\pi}}$ & 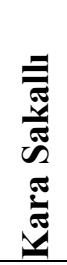 & 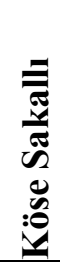 & 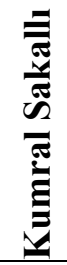 & 离 & 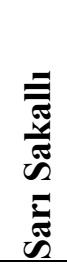 & 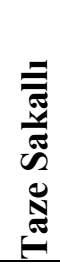 & 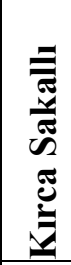 & 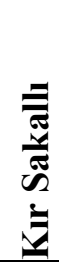 & 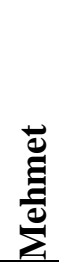 & $\overrightarrow{\mathrm{E}}$ & 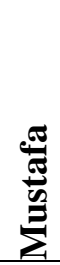 & 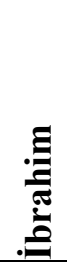 & : & 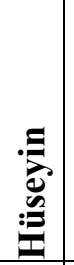 & $\bar{z}$ & ठัٌ & 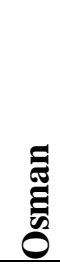 \\
\hline 5 & $\begin{array}{l}2 \\
8\end{array}$ & 24 & 2 & $\begin{array}{l}2 \\
3 \\
\end{array}$ & $\begin{array}{l}1 \\
3\end{array}$ & 6 & 4 & 2 & 1 & $\begin{array}{l}2 \\
0\end{array}$ & $\begin{array}{l}1 \\
5\end{array}$ & $\begin{array}{l}1 \\
0\end{array}$ & 9 & 8 & 7 & 7 & 7 & 4 \\
\hline
\end{tabular}




\section{Süleymaniye Râbi a Medresesi}

Süleymaniye Mahallesi Mimar Sinan Caddesindedir. 1844 yılı sayımına göre 117 kişi bulunmaktadır. 27 farklı isim kullanılmıştır. 3 kişi çift isimlidir. En fazla Mehmet ismi kullanılmıştır Medresenin yaş ortalaması 22'dir. En yaşlı olan kişi 46, en küçük olanı ise 13 yaşındadır. Fizikî özellik olarak 6 kişi kısa, 57 kişi orta, 16 kişi uzun boyludur. Medresede 22 oda vardır. 2 ve 6 numaralı odalar boştur. Bir kişi mülazımdır. 9 kişi Geyveli, 6 kişi Denizlili, 5 kişi Ezinelidir.

Tablo 7: Medrese-i Râbi a der-Süleymaniye’ye Kayıtlı Olan Kişilerin Genel Özellikleri

\begin{tabular}{|c|c|c|c|c|c|c|c|c|c|c|c|c|c|c|c|c|c|}
\hline \multicolumn{6}{|c|}{ Yaş Aralığı } & \multicolumn{5}{|c|}{ Boy } & \multicolumn{7}{|c|}{ Memleket } \\
\hline \multicolumn{2}{|c|}{ 0-14 } & \multicolumn{2}{|c|}{\begin{tabular}{|l|}
$15-39$ \\
\end{tabular}} & \multicolumn{2}{|c|}{$\begin{array}{ll}40 & \text { ve } \\
+ & \end{array}$} & Kisa & \multicolumn{2}{|c|}{ Orta } & \multicolumn{2}{|c|}{ Uzun } & \multicolumn{3}{|c|}{$\begin{array}{l}\text { Anadol } \\
\text { u }\end{array}$} & \multicolumn{2}{|c|}{$\begin{array}{l}\text { Balkanla } \\
\mathbf{r}\end{array}$} & \multicolumn{2}{|c|}{ Diğer } \\
\hline \multicolumn{2}{|c|}{$\begin{array}{l}7 \\
\text { kişi }\end{array}$} & \multicolumn{2}{|c|}{106 kişi } & \multicolumn{2}{|c|}{4 kişi } & 6 kiş & \multicolumn{2}{|c|}{$\begin{array}{l}57 \\
\text { kişi }\end{array}$} & \multicolumn{2}{|c|}{16 kişi } & \multicolumn{3}{|c|}{94 kişi } & \multicolumn{2}{|c|}{8 kişi } & \multicolumn{2}{|c|}{14 kişi } \\
\hline \multicolumn{10}{|c|}{ Sakal-Bıyık } & \multicolumn{8}{|c|}{ İsim } \\
\hline 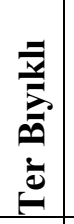 & 音 & 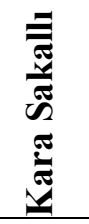 & 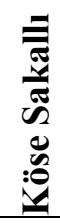 & 䴇 & 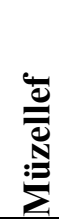 & 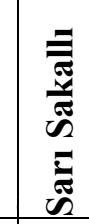 & 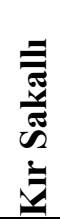 & 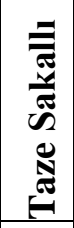 & 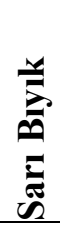 & 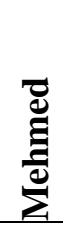 & 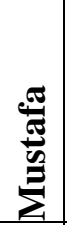 & $\bar{z}$ & 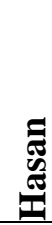 & 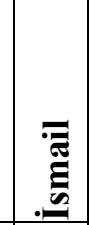 & $\begin{array}{l}\tilde{E} \\
\tilde{E} \\
\text { ర్ }\end{array}$ & 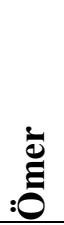 & 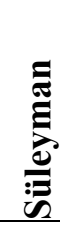 \\
\hline $\begin{array}{l}1 \\
1\end{array}$ & $\begin{array}{l}\mathbf{3} \\
\mathbf{0}\end{array}$ & 18 & 6 & $\begin{array}{l}1 \\
5\end{array}$ & $\begin{array}{l}2 \\
4\end{array}$ & 8 & 1 & 1 & 1 & $\begin{array}{l}2 \\
5\end{array}$ & $\begin{array}{l}1 \\
6\end{array}$ & 9 & 9 & 8 & 7 & 6 & 5 \\
\hline
\end{tabular}

\section{Süleymaniye Hilâlci Medresesi}

1844 yılı sayımına göre medresede 58 kişi vardır. 20 farklı isim kullanılmıştır. Mehmet ve Mustafa en fazla kullanılan isimlerdir. Bir kişi çift isimlidir (Mehmed Said). 6 kişi Bodrumlu, 5 kişi Lapsekili, 4 kişi İçellidir. Medresesin yaş ortalaması 23'tür. En yaşlı kişi 45 yaşında en küçük ise 8 yaşındadır. Fizikî evsaf olarak 4 kişi kısa, 22 kişi orta, 10 kişi uzun boyludur. Medresede 10 oda bulunmaktadır. 10 numaralı oda boştur. 1 kişi mülazımdır. 
Tablo 8: Medrese-i Derûn Hâne-i Hilâlci Der-Süleymaniye’ye Kayıtlı Olan Kişilerin Genel Özellikleri

\begin{tabular}{|c|c|c|c|c|c|c|c|c|c|c|c|c|c|c|c|c|c|c|}
\hline \multicolumn{5}{|c|}{ Yaş Aralığg } & \multicolumn{6}{|c|}{ Boy } & \multicolumn{8}{|c|}{ Memleket } \\
\hline \multicolumn{2}{|c|}{$0-14$} & \multicolumn{2}{|c|}{$15-39$} & $\begin{array}{l}40 \text { ve } \\
+\quad \\
\end{array}$ & \multicolumn{2}{|c|}{ Kisa } & \multicolumn{2}{|c|}{ Orta } & \multicolumn{2}{|c|}{ Uzun } & \multicolumn{3}{|c|}{$\begin{array}{l}\text { Anadol } \\
\mathbf{u}\end{array}$} & \multicolumn{3}{|c|}{$\begin{array}{l}\text { Balkanla } \\
\mathbf{r}\end{array}$} & \multicolumn{2}{|c|}{ Diğer } \\
\hline \multicolumn{2}{|c|}{$\begin{array}{l}4 \\
\text { kişi }\end{array}$} & \multicolumn{2}{|c|}{53 kişi } & 1 kişi & \multicolumn{2}{|c|}{\begin{tabular}{|l|}
4 \\
kişi
\end{tabular}} & \multicolumn{2}{|c|}{22 kişi } & \multicolumn{2}{|c|}{10 kişi } & \multicolumn{3}{|c|}{47 kişi } & \multicolumn{3}{|c|}{4 kişi } & \multicolumn{2}{|c|}{6 kişi } \\
\hline \multicolumn{7}{|c|}{ Sakal-Bıyık } & \multicolumn{12}{|c|}{ İsim } \\
\hline 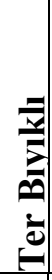 & 育 & 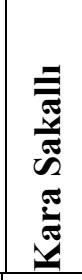 & 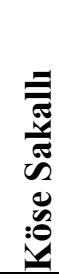 & 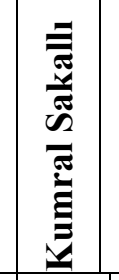 & 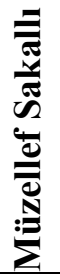 & 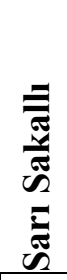 & 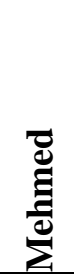 & $\frac{\underset{\pi}{\pi}}{\stackrel{\pi}{\pi}}$ & 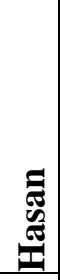 & $\gtreqless$ & 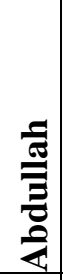 & 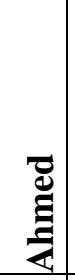 & $\begin{array}{l}\equiv \\
0 \\
0\end{array}$ & • & 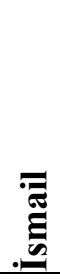 & قَّ: & $\begin{array}{l}0 \\
\frac{\pi}{\pi} \\
\bar{\nu}\end{array}$ & 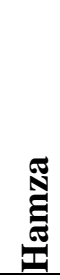 \\
\hline 3 & 8 & 16 & 1 & 8 & 9 & 3 & 15 & 8 & 6 & 5 & 2 & 2 & 2 & 2 & 2 & 2 & 2 & 1 \\
\hline
\end{tabular}

\section{Siyavuş Paşa Sultanî Medresesi}

III. Murat devri sadrazamlarından Siyavuş Paşa tarafından yaptırılmıştır. 1792 tarihinde yapılan sayımda 33 kişi kayıtlıdır. 1844 sayımında 69 kişi bulunmaktadır. 25 farklı isim kullanılmıştır. Ahmet, Mehmet ve Ali en fazla kullanılan isimlerdir. 5 farklı çift isim vardır. Medresenin yaş ortalaması 23'tür. En yaşlı kişi 55, en küçük olan ise 8 yaşındadır. Fizikî özellik olarak 4 kişi kısa, 22 kişi orta, 4 kişi uzun boyludur.

Medresede 15 oda bulunmaktadır. 14 ve 15 numaralı odalar boştur. 1 kişi mülazımdır. 13 kişi Safranbolulu, 4 kişi İzmitli, 4 kişi Kastamonuludur. 59-116 sıraları arasında bulunan sayfalar mevcut değildir. 1869 sayımında medresede 57 kişi bulunmaktadır ${ }^{31}$. 1914 tarihli rapora göre 20 talebe ikamet edebilir. Bugün bakımsız durumdadır. Bazı bölmeleri özel atölye ve depo olarak kullanılmaktadır.

31 Mübahat Kütükoğlu, “1869'da Faal İstanbul Medreseleri”, Tarih Enstitüsü Dergisi, Say1 7-8, Edebiyat Fakültesi Matbaası, İstanbul 1977, s. 288. 
Tablo 9: Medrese-i Siyavuş Paşa-yı Sultanî Kurb-1 Beyoğlu'na Kayıtlı Olan Kişilerin Genel Özellikleri

\begin{tabular}{|c|c|c|c|c|c|c|c|c|c|c|c|c|c|c|c|c|c|c|c|}
\hline \multicolumn{6}{|c|}{ Yaș Aralığı } & \multicolumn{6}{|c|}{ Boy } & \multicolumn{8}{|c|}{ Memleket } \\
\hline \multicolumn{2}{|c|}{$0-14$} & \multicolumn{2}{|c|}{ 15-39 } & \multicolumn{2}{|c|}{$\begin{array}{ll}40 & \text { ve } \\
+\end{array}$} & \multicolumn{2}{|c|}{ Kisa } & \multicolumn{2}{|c|}{ Orta } & \multicolumn{2}{|c|}{$\begin{array}{l}\text { Uzu } \\
\text { n }\end{array}$} & \multicolumn{2}{|c|}{$\begin{array}{l}\text { Anadol } \\
\text { u }\end{array}$} & \multicolumn{3}{|c|}{$\begin{array}{l}\text { Balkanla } \\
\mathbf{r}\end{array}$} & \multicolumn{3}{|c|}{ Diğer } \\
\hline \multicolumn{2}{|c|}{$\begin{array}{l}10 \\
\text { kişi }\end{array}$} & \multicolumn{2}{|c|}{57 kişi } & \multicolumn{2}{|c|}{2 kişi } & \multicolumn{2}{|c|}{4 kişi } & \multicolumn{2}{|c|}{22 kişi } & \multicolumn{2}{|c|}{$\begin{array}{l}4 \\
\text { kişi }\end{array}$} & \multicolumn{2}{|c|}{55 kişi } & \multicolumn{3}{|c|}{2 kişi } & \multicolumn{3}{|c|}{12 kişi } \\
\hline \multicolumn{10}{|c|}{ Sakal-Bıyık } & \multicolumn{10}{|c|}{ İsim } \\
\hline & $\frac{0}{\frac{0}{\pi}}$ & 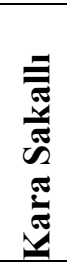 & 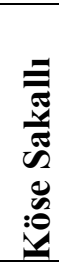 & 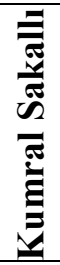 & 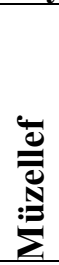 & 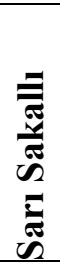 & 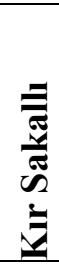 & 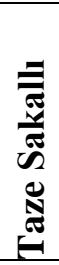 & 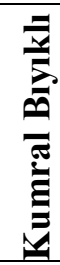 & 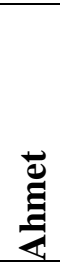 & 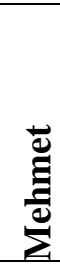 & $\bar{z}$ & 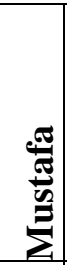 & 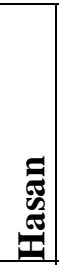 & 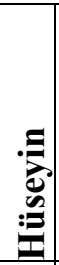 & 馬 & 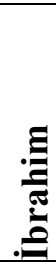 & 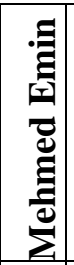 & $\bar{E}$ \\
\hline 3 & $\begin{array}{l}1 \\
6\end{array}$ & $\begin{array}{l}1 \\
3\end{array}$ & 1 & $\begin{array}{l}1 \\
2\end{array}$ & 7 & 3 & 1 & 1 & 1 & $\begin{array}{l}\mathbf{1} \\
\mathbf{0}\end{array}$ & 9 & 6 & 5 & 4 & 4 & 4 & 3 & 3 & 3 \\
\hline
\end{tabular}

\section{Kepenekçi Sinan Medresesi}

Medrese, Kanuni Devri ulemasından Kepenekçi Hoca Sinan tarafindan yaptırılmıştır. 1792 tarihinde 11 hücrede toplam 19 kişinin kaldığ 1 bilinmektedir. 1844 yılı sayımında 46 kişi kalmaktadır. 21 farklı isim kullanılmıştır. Mehmet, Ali, Ahmet en fazla kullanılan isimlerdir. Medresenin yaş ortalaması 21 'dir. En yaşlı kişi 40, en küçük kişi ise 12 yaşındadır. Fizikî özellik olarak 2 kişi kısa, 15 kişi orta, 6 kişi de uzun boyludur. Medresede 9 oda vardır. 5 ve 8 numaralı odalar boştur. 1 kişi mülazımdır. 5 kişi Kastamonulu, 3 kişi Ankaralı, 3 kişi Varnalıdır. 1869 sayımında 28 kişi kalmaktadır. 1914 tarihli rapora göre 10 kişinin kalması uygundur. Günümüzde harap bir vaziyettedir.

Tablo 10: Medrese-i Kepenekçi Sinan Kurb-1 Beyoğlu'na Kayıtlı Olan Kişilerin Genel Özellikleri

\begin{tabular}{|c|c|c|c|c|c|c|c|c|c|c|c|c|c|c|c|c|c|c|c|}
\hline \multicolumn{5}{|c|}{ Yaş Aralığg } & \multicolumn{7}{|c|}{ Boy } & \multicolumn{8}{|c|}{ Memleket } \\
\hline \multicolumn{2}{|c|}{ 0-14 } & \multicolumn{2}{|c|}{$15-39$} & $\begin{array}{ll}40 & \mathrm{ve} \\
+ & \\
\end{array}$ & \multicolumn{2}{|c|}{ Kisa } & \multicolumn{2}{|c|}{ Orta } & \multicolumn{3}{|c|}{ Uzun } & \multicolumn{2}{|c|}{$\begin{array}{l}\text { Anadol } \\
\text { u }\end{array}$} & \multicolumn{4}{|c|}{ Balkanlar } & \multicolumn{2}{|c|}{$\begin{array}{l}\text { Diğe } \\
\text { r }\end{array}$} \\
\hline $\begin{array}{l}6 \\
\text { kişi }\end{array}$ & \multicolumn{3}{|c|}{38 kişi } & 2 kişi & \multicolumn{2}{|c|}{$\begin{array}{l}2 \\
\text { kişi }\end{array}$} & \multicolumn{2}{|c|}{15 kişi } & \multicolumn{3}{|c|}{6 kişi } & \multicolumn{2}{|c|}{34 kişi } & \multicolumn{4}{|c|}{4 kişi } & \multicolumn{2}{|c|}{$\begin{array}{l}8 \\
\text { kişi }\end{array}$} \\
\hline \multicolumn{6}{|c|}{ Sakal-Bıyık } & \multicolumn{14}{|c|}{ İsim } \\
\hline 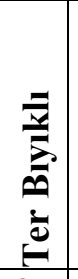 & $\frac{2}{\pi}$ & 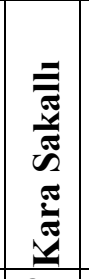 & 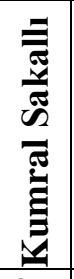 & 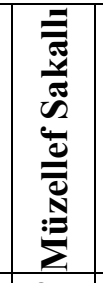 & 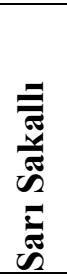 & 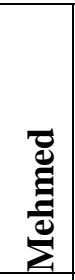 & $\because$ & 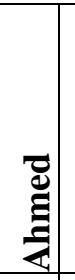 & 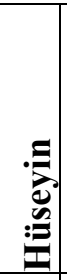 & $\frac{\frac{\pi}{5}}{\stackrel{5}{\sigma}}$ & $\begin{array}{l}\bar{\Xi} \\
\end{array}$ & $\begin{array}{l}\mathbf{E} \\
\overline{\mathbf{E}} \\
\mathbf{E} \\
\bar{Z}\end{array}$ & $\frac{2}{2}$ & 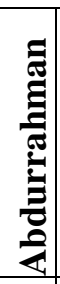 & $\begin{array}{l}\mathbf{Z} \\
\mathbf{Z} \\
\mathbf{Z} \\
\mathbf{\Xi} \\
\mathbf{Z}\end{array}$ & 驀 & 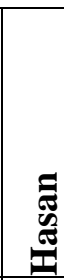 & قِ. & 宗 \\
\hline 3 & $\begin{array}{l}1 \\
3\end{array}$ & 8 & 9 & 3 & 3 & 7 & 6 & 5 & 4 & 3 & 3 & 2 & 1 & 1 & 1 & 1 & 1 & 1 & 1 \\
\hline
\end{tabular}




\section{1. Şehzâde Medresesi}

Kanuni Sultan Süleyman tarafindan oğlu Mehmet için Mimar Sinan’a yaptırılmıştır. Cami, sıbyan mektebi, tabhâne, imâret, türbe ve fırından müteşekkil Şehzâde Külliyesi'nin parçası olup 1543'te inşaatına başlanıp Farsça kitabesine göre 1547'de tamamlanmıştır. Medrese iki katlıdır. Fevkanîde 22 odası bulunmaktadır. 1844 sayımına göre 116 kişi vardır. 31 farklı isim kullanılmıştır. Ahmet, Mehmet, Ali en fazla kullanılan isimlerdir. Medresenin yaş ortalaması 22'dir. En yaşlı kişi 51, en küçük kişi ise 8 yaşındadır. Medresede 20 oda bulunmaktadır. 2, 5, 6, 8, 12, 17 ve 19 numaralı odalar boştur. 1 kişi mülazımdır. Fizikî özellik olarak 5 kişi kısa, 64 orta, 15 kişi uzun boyludur. 15 kişi Bosnalı, 5 kişi Asitaneli (İstanbul), 4 kişi Eskişehirlidir. 1869 sayımına göre medresede toplam 61 kişi kayıtlıdır. 3 kişi mülazımdır. 1914 raporuna göre 25 kişi ikamet edebilir ${ }^{32}$.

Tablo 11: Medrese-i Şehzâde-i Derûn Câmi 'i Şerif’e Kayıtlı Olan Kişilerin Genel Özellikleri

\begin{tabular}{|c|c|c|c|c|c|c|c|c|c|c|c|c|c|c|c|c|c|c|}
\hline \multicolumn{6}{|c|}{ Yaş Aralığı } & \multicolumn{6}{|c|}{ Boy } & \multicolumn{7}{|c|}{ Memleket } \\
\hline \multicolumn{2}{|c|}{$0-14$} & \multicolumn{2}{|c|}{$15-39$} & \multicolumn{2}{|c|}{$\begin{array}{l}40 \text { ve } \\
+\quad \\
\end{array}$} & \multicolumn{2}{|c|}{ Kisa } & \multicolumn{2}{|c|}{ Orta } & \multicolumn{2}{|c|}{ Uzun } & \multicolumn{2}{|c|}{$\begin{array}{l}\text { Anadol } \\
\text { u }\end{array}$} & \multicolumn{3}{|c|}{$\begin{array}{l}\text { Balkanla } \\
\mathbf{r}\end{array}$} & \multicolumn{2}{|c|}{ Diğer } \\
\hline \multicolumn{2}{|c|}{12 kişi } & \multicolumn{2}{|c|}{97 kişi } & \multicolumn{2}{|c|}{7 kişi } & \multicolumn{2}{|c|}{$\begin{array}{l}5 \\
\text { kişi }\end{array}$} & \multicolumn{2}{|c|}{64 kişi } & \multicolumn{2}{|c|}{15 kişi } & \multicolumn{2}{|c|}{74 kişi } & \multicolumn{3}{|c|}{26 kişi } & \multicolumn{2}{|c|}{16 kişi } \\
\hline \multicolumn{11}{|c|}{.Sakal-Bıyık } & \multicolumn{8}{|c|}{ İsim } \\
\hline 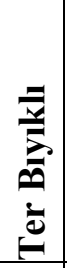 & 竞 & 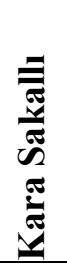 & 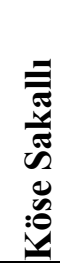 & 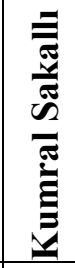 & 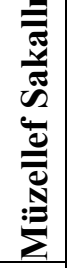 & 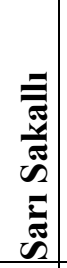 & 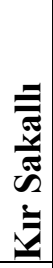 & 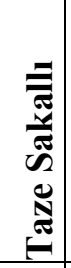 & 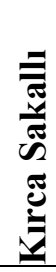 & 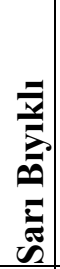 & 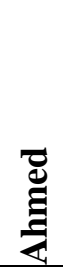 & 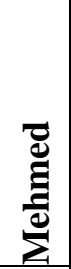 & 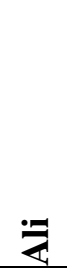 & : & 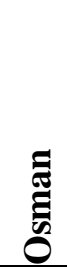 & 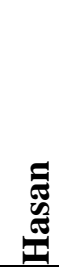 & 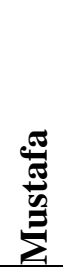 & 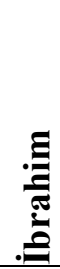 \\
\hline $\begin{array}{l}1 \\
5\end{array}$ & $\begin{array}{l}2 \\
8\end{array}$ & 15 & 1 & $\begin{array}{l}2 \\
4\end{array}$ & $\begin{array}{l}1 \\
2\end{array}$ & 5 & 1 & 1 & 1 & 1 & $\begin{array}{l}2 \\
\mathbf{0}\end{array}$ & $\begin{array}{l}1 \\
5\end{array}$ & $\begin{array}{l}1 \\
\mathbf{0}\end{array}$ & 8 & 8 & 7 & 7 & 6 \\
\hline
\end{tabular}

\section{Etmekçizâde Ahmed Paşa Medresesi}

Sultan I. Ahmet devri vezirlerinden Etmekçizâde Ahmed Paşa tarafindan yaptırılmıştır. 1844 yılı sayımında 73 kişi mevcuttur. 28 farklı isim kullanılmıştır. Ahmet, Mehmet, Mustafa en fazla kullanılan isimlerdir. 4 kişi çift isimlidir. Medresenin

\footnotetext{
${ }^{32}$ Kütükoğlu, a.g.m., s. 78.
} 
yaş ortalaması 24'tür. En yaşlı olan kişi 55, en küçük ise 11 yaşındadır. Fizikî evsaf olarak 2 kişi kısa, 41 kişi orta, 8 kişi uzun boyludur. Medresede 18 oda vardır. 4, 6, 17 numaralı odalar boştur. 2 kişi mülazımdır. 26 kişi Bosnalı, 7 kişi Kastamonuludur. 1869 da 55 kişi bulunmaktadır. 1914 tarihli rapora göre; zemine bitişik, bazı odalarının arka kısmında penceresi olan hava almaya müsait ve güneş 1şı̆̆ından mahrum 17 odası vardır. 20 kişi ikamet edebilir.

Tablo 12: Medrese-i Etmekçizâde Ahmed Paşa Kurb-1 Vikaye’ye Kayıtlı Olan Kişilerin Genel Özellikleri

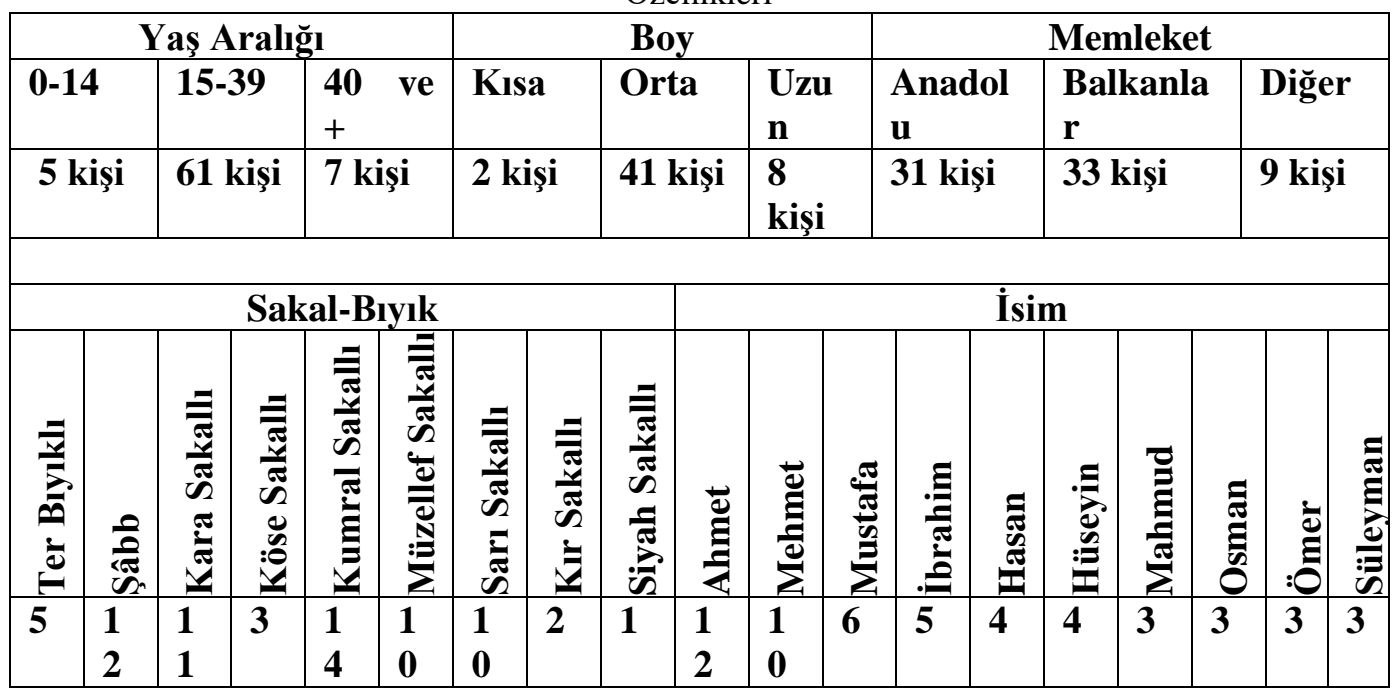

\section{3. Şeyh Ebu'l-Vefa Kirmasti Medresesi}

Medresede, 1844 sayımına göre 27 kişi bulunmaktadır. 14 farklı isim kullanılmıştır. Mehmet ve Ali en fazla kullanılan isimledir. Medresenin yaş ortalaması 21 'dir. En yaşlı kişi 51, en küçük kişi ise 10 yaşındadır. Fizikî özellik olarak 2 kişi kısa, 17 kişi orta, 1 kişi uzun boyludur. Medresede 7 oda bulunmaktadır. 1 ve 5 numaralı odalar boştur. 2 kişi mülazımdır. 4 kişi Kütahyalı, 3 kişi Şumnuludur. 1869 tarihli sayıma göre medresede 21 kişi kayıtlıdır. 8 odası vardır. 1918'deki Vefa yangınında yanmıştır. 1914 tarihli rapora göre; talebe iskânına uygun değildir. 10 kişi ikamet edebilir. 
Tablo 13: Medrese-i Kirmasti Kurb-1 Şeyh Ebu'l-Vefa'ya Kayıtlı Olan Kişilerin Genel Özellikleri

\begin{tabular}{|c|c|c|c|c|c|c|c|c|c|c|c|c|c|c|c|c|c|c|}
\hline \multicolumn{5}{|c|}{ Yaş Aralığı } & \multicolumn{6}{|c|}{ Boy } & \multicolumn{8}{|c|}{ Memleket } \\
\hline \multirow{2}{*}{\multicolumn{2}{|c|}{\begin{tabular}{|l|}
$0-14$ \\
5 kişi
\end{tabular}}} & \multirow{2}{*}{\multicolumn{2}{|c|}{\begin{tabular}{l|}
$15-39$ \\
19 kişi
\end{tabular}}} & $\begin{array}{ll}40 & \text { ve } \\
+ & \\
\end{array}$ & \multicolumn{2}{|c|}{ Kisa } & \multicolumn{2}{|c|}{ Orta } & \multicolumn{2}{|c|}{ Uzun } & \multicolumn{3}{|c|}{ Anadolu } & \multicolumn{3}{|c|}{\begin{tabular}{|l} 
Balkanla \\
$\mathbf{r}$
\end{tabular}} & \multicolumn{2}{|c|}{ Diğer } \\
\hline & & & & 3 kişi & \multicolumn{2}{|c|}{2 kişi } & \multicolumn{2}{|c|}{17 kişi } & \multicolumn{2}{|c|}{1 kişi } & \multicolumn{3}{|c|}{17 kişi } & \multicolumn{3}{|c|}{4 kişi } & \multicolumn{2}{|c|}{6 kişi } \\
\hline \multicolumn{5}{|c|}{ Sakal-Bıyık } & \multicolumn{14}{|c|}{ İsim } \\
\hline 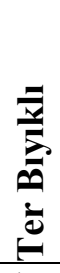 & 产 & 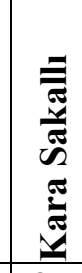 & 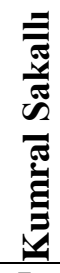 & 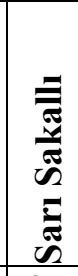 & 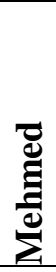 & 运 & & 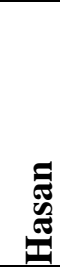 & 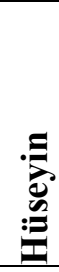 & 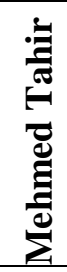 & 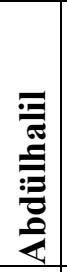 & : & 䍖 & 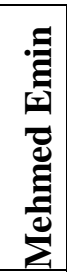 & 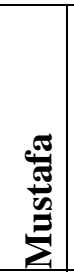 & 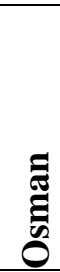 & 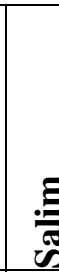 & 㲵 \\
\hline 1 & 10 & 3 & 5 & 3 & 8 & 3 & 2 & 2 & 2 & 2 & 1 & 1 & 1 & 1 & 1 & 1 & 1 & 1 \\
\hline
\end{tabular}

\section{Emrullah Hoca Medresesi}

1844 tarihli sayıma göre 25 kişi bulunmaktadır. 15 farklı isim kullanılmıştır. Ömer, Abdullah, Ahmet ve Mehmet en fazla kullanılan isimlerdir. Medresenin yaş ortalaması 23'tür. En yaşlı kişi 60, en küçük kişi ise 12 yaşındadır. Fizikî evsaf olarak 1 kişi kısa, 14 kişi orta, 1 kişi uzun boyludur. Medresede 6 oda bulunmaktadır. 1 kişi mülazımdır. 2 kişi Filibe, 2 kişi Beydere, 2 kişi Hacıoğlu Pazarcıklıdır.

Tablo 14: Medrese-i Emrullah Hoca Kurb-1 Bozdoğan Kemeri’ne Kayıtlı Olan Kişilerin Genel Özellikleri

\begin{tabular}{|c|c|c|c|c|c|c|c|c|c|c|c|c|c|c|c|c|c|c|c|c|}
\hline \multicolumn{6}{|c|}{ Yaş Aralığı } & \multicolumn{6}{|c|}{ Boy } & \multicolumn{9}{|c|}{ Memleket } \\
\hline \multicolumn{2}{|c|}{$0-14$} & \multicolumn{2}{|c|}{$15-39$} & \multicolumn{2}{|c|}{$\begin{array}{ll}40 & \text { ve } \\
+ & \end{array}$} & \multicolumn{2}{|c|}{ Kisa } & \multicolumn{2}{|c|}{ Orta } & \multicolumn{2}{|c|}{ Uzun } & \multicolumn{3}{|c|}{$\begin{array}{l}\text { Anadol } \\
\text { u }\end{array}$} & \multicolumn{3}{|c|}{$\begin{array}{l}\text { Balkanla } \\
\mathbf{r}\end{array}$} & \multicolumn{3}{|c|}{ Diğer } \\
\hline \multicolumn{2}{|c|}{$\begin{array}{l}3 \\
\text { kişi }\end{array}$} & \multicolumn{2}{|c|}{21 kişi } & \multicolumn{2}{|c|}{1 kişi } & \multicolumn{2}{|c|}{$\begin{array}{l}1 \\
\text { kisi }\end{array}$} & \multicolumn{2}{|c|}{14 kişi } & \multicolumn{2}{|c|}{1 kişi } & \multicolumn{3}{|c|}{13 kişi } & \multicolumn{3}{|c|}{7 kişi } & \multicolumn{3}{|c|}{5 kişi } \\
\hline \multicolumn{6}{|c|}{ Sakal-Bıyık } & \multicolumn{15}{|c|}{ İsim } \\
\hline$\frac{0}{\frac{\pi}{\pi}}$ & 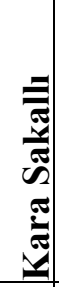 & 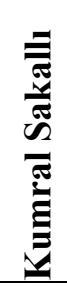 & 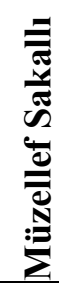 & 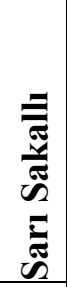 & 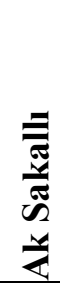 & :ढّ & 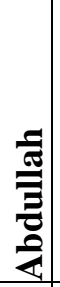 & 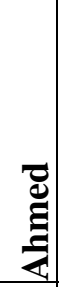 & 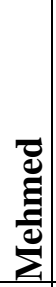 & 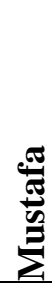 & 娄 & : & 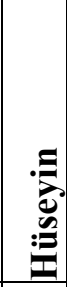 & 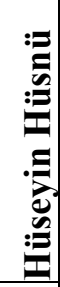 & 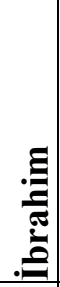 & 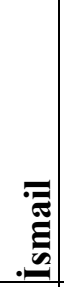 & 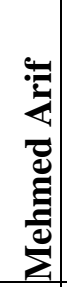 & 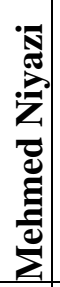 & 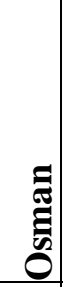 & 氞 \\
\hline 8 & 5 & 5 & 3 & 2 & 1 & 4 & 3 & 3 & 3 & 2 & 1 & 1 & 1 & 1 & 1 & 1 & 1 & 1 & 1 & 1 \\
\hline
\end{tabular}

\section{Yahyagüzel Medresesi}

1844 yılı sayımında Defterde 20 kişi kayıtlıdır. 13 farklı isim kullanılmıştır. Ahmet, Hasan, Mahmut en fazla kullanılan isimlerdir. Medresenin yaş ortalaması 22 'dir. En yaşlı kişi 42, en küçük kişi ise 12 yaşındadır. Fizikî evsaf olarak 2 kişi kısa, 12 kişi orta, 1 kişi uzun boyludur. Medresede 6 oda vardır. 5 numaralı oda boştur. 1 kişi 
mülazımdır. 5 kişi Ayaşı1, 2 kişi Çankırılıdır. 1914 raporuna göre 3 odası ve 1 bekçi barakası ile 6 odaya sahiptir. Temiz hava almaya uygun değildir. Güneş ışı̆̆ından mahrumdur. Kesinlikle talebe kalamaz. Mevcut 4 talebesi vardır. 6 talebe kalabilir.

Tablo 15: Medrese-i Yahyagüzel Kurb-1 Şeyh Ebu'l-Vefa'ya Kayıtlı Olan Kişilerin Genel Özellikleri

\begin{tabular}{|c|c|c|c|c|c|c|c|c|c|c|c|c|c|c|c|c|c|}
\hline \multicolumn{6}{|c|}{ Yaș Aralığı } & \multicolumn{5}{|c|}{ Boy } & \multicolumn{7}{|c|}{ Memleket } \\
\hline \multicolumn{2}{|c|}{ 0-14 } & \multicolumn{2}{|c|}{$15-39$} & \multicolumn{2}{|c|}{$\begin{array}{ll}40 & \text { ve } \\
+ & \\
\end{array}$} & Kisa & \multicolumn{3}{|c|}{ Orta } & Uzun & \multicolumn{3}{|c|}{ Anadolu } & \multicolumn{2}{|c|}{$\begin{array}{l}\text { Balkanla } \\
\mathbf{r}\end{array}$} & \multicolumn{2}{|c|}{$\begin{array}{l}\text { Diğe } \\
\mathbf{r}\end{array}$} \\
\hline \multicolumn{2}{|c|}{1 kişi } & \multicolumn{2}{|c|}{$\begin{array}{l}18 \\
\text { kişi }\end{array}$} & \multicolumn{2}{|c|}{1 kişi } & $\begin{array}{l}2 \\
\text { kişi }\end{array}$ & \multicolumn{3}{|c|}{12 kişi } & 1 kişi & \multicolumn{3}{|c|}{15 kişi } & \multicolumn{2}{|c|}{1 kişi } & \multicolumn{2}{|c|}{$\begin{array}{l}2 \\
\text { kişi }\end{array}$} \\
\hline \multicolumn{5}{|c|}{ Sakal-Bıyık } & \multicolumn{13}{|c|}{ İsim } \\
\hline$\frac{0}{8}$ & 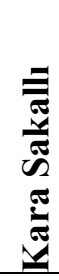 & 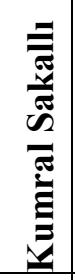 & 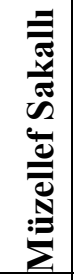 & 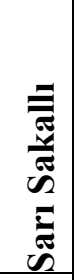 & $\underset{\mathbb{E}}{\mathbb{E}}$ & 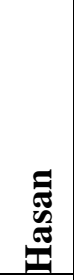 & 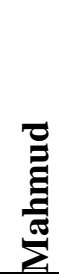 & 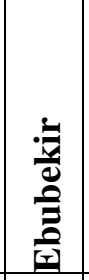 & $\begin{array}{l}. \\
0 \\
0\end{array}$ & 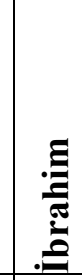 & 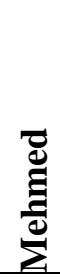 & 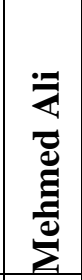 & $\stackrel{\mathscr{g}}{\Xi}$ & 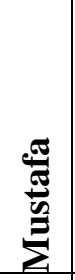 & 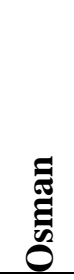 & 苋 & 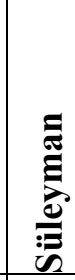 \\
\hline 8 & 2 & 5 & 2 & 1 & 5 & 3 & 2 & 1 & 1 & 1 & 1 & 1 & 1 & 1 & 1 & 1 & 1 \\
\hline
\end{tabular}

\section{6. Şeyh Ebu'l-Vefa Medresesi}

Şeyh Ebu'l-Vefa, Fatih devrinde yaşamış büyük bir mutasavvıftır. Fatih devrinde başlanan medresenin yapımı II. Bayezid devrinde sona ermiştir. 1792'de yapılan sayımda 15 kişi bulunmaktadır. 1844 sayımına göre mevcut 38 kişidir. 20 farklı isim kullanılmıştır. Mehmet, Mustafa, Abdullah ve Ali en fazla kullanılan isimlerdir. Medresenin yaş ortalaması 24'tür. En yaşlı kişi 50 yaşında, en küçük kişi ise 12 yaşındadır. Fizikî evsaf olarak 1 kişi kısa, 21 kişi orta, 8 kişi uzun boyludur. Medresede 15 oda vardır. 5 numaralı oda boştur. 1 kişi mülazımdır. Geyveli 6 kişi, İçelli 3 kişi, Varnalı 3 kişi vardır. 1869'da 36 kişi vardır. 1912 deki yangında büyük hasar görmüştür. 1914 tarihli rapora göre 20 talebe ikamet edebilir. 
Tablo 16: Medrese-i Şeyh Ebu'l-Vefa Derûn Cami' -i Şerif'e Kayıtlı Olan Kişilerin Genel Özellikleri

\begin{tabular}{|c|c|c|c|c|c|c|c|c|c|c|c|c|c|c|c|c|c|c|c|c|c|}
\hline \multicolumn{6}{|c|}{ Yaș Aralığı } & \multicolumn{7}{|c|}{ Boy } & \multicolumn{9}{|c|}{ Memleket } \\
\hline \multicolumn{2}{|c|}{$0-14$} & \multicolumn{2}{|c|}{$15-39$} & \multicolumn{2}{|c|}{$\begin{array}{ll}40 & \text { ve } \\
+\end{array}$} & \multicolumn{2}{|c|}{ Kisa } & \multicolumn{3}{|c|}{ Orta } & \multicolumn{2}{|c|}{ Uzun } & \multicolumn{3}{|c|}{$\begin{array}{l}\text { Anadol } \\
\text { u }\end{array}$} & \multicolumn{3}{|c|}{$\begin{array}{l}\text { Balkanla } \\
\mathbf{r}\end{array}$} & \multicolumn{3}{|c|}{ Diğer } \\
\hline \multicolumn{2}{|l|}{$\begin{array}{l}3 \\
\text { kişi }\end{array}$} & \multicolumn{2}{|c|}{34 kişi } & \multicolumn{2}{|c|}{1 kişi } & \multicolumn{2}{|c|}{1 kişi } & \multicolumn{3}{|c|}{21 kişi } & \multicolumn{2}{|c|}{8 kişi } & \multicolumn{3}{|c|}{28 kişi } & \multicolumn{3}{|c|}{3 kişi } & \multicolumn{3}{|c|}{5 kişi } \\
\hline \multicolumn{6}{|c|}{ Sakal-Bıyık } & \multicolumn{16}{|c|}{ İsim } \\
\hline 离. & 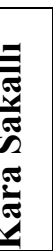 & 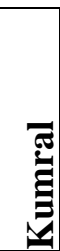 & $\mid$ & 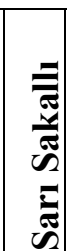 & 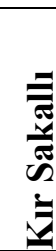 & 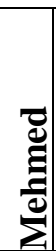 & 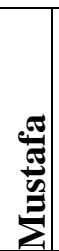 & 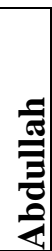 & 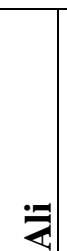 & 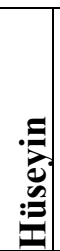 & 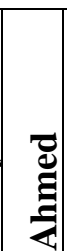 & 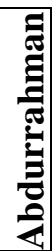 & 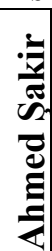 & 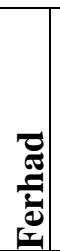 & 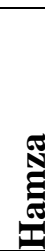 & 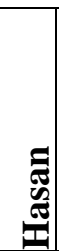 & 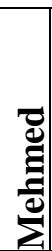 & 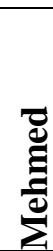 & 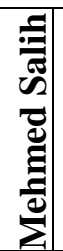 & 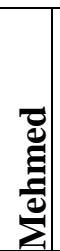 & $\stackrel{5}{2}$ \\
\hline \begin{tabular}{l|l}
7 & 1
\end{tabular} & $\mathbf{0}$ & 8 & 8 & 3 & 1 & 9 & 4 & 3 & 3 & 3 & 2 & 1 & 1 & 1 & 1 & 1 & 1 & 1 & 1 & 1 & 1 \\
\hline
\end{tabular}

\section{Süleymaniye Kirazlı Mescid Subaşı Medresesi}

1844 sayımına göre 52 kişi bulunmaktadır. 21 farklı isim kullanılmıştır. Ali, Mehmet, Hüseyin en fazla kullanılan isimlerdir. Medresenin yaş ortalaması 24'tür. En büyük kişi 50, en küçük kişi ise 12 yaşındadır. Fizikî evsaf olarak 1 kişi kısa, 27 kişi orta, 8 kişi uzun boyludur. Medresede 15 oda vardır. 9 ve 10 numaralı odalar boştur. 1 kişi mülazımdır. 5 kişi İzmitli, 4 kişi Kastamonuludur. 1914 raporuna göre zemine bitişik, avluya bakan, 18 odası bulunmaktadır. Odaları güneş ışığı ve temiz hava almaya uygun değildir. Müştemilatı genel itibariyle harap durumdadır. Binalar arasında kaldığından ikamete uygun değildir. 25 talebe iskân edebilir.

Tablo 17: Medrese-i Süleymaniye Subaşı Der-Kirazlı Mescid’e Kayıtlı Olan Kişilerin Genel Özellikleri

\begin{tabular}{|c|c|c|c|c|c|c|c|c|c|c|c|c|c|c|c|c|c|c|c|}
\hline \multicolumn{5}{|c|}{ Yaş Aralığı } & \multicolumn{6}{|c|}{ Boy } & \multicolumn{9}{|c|}{ Memleket } \\
\hline \multicolumn{2}{|c|}{ 0-14 } & \multicolumn{2}{|c|}{\begin{tabular}{|l|}
$15-39$ \\
\end{tabular}} & $\begin{array}{ll}40 & \text { ve } \\
+ & \\
\end{array}$ & \multicolumn{2}{|c|}{ Kisa } & \multicolumn{3}{|c|}{ Orta } & $\begin{array}{l}\text { Uzu } \\
\text { n }\end{array}$ & \multicolumn{3}{|c|}{$\begin{array}{l}\text { Anadol } \\
\text { u }\end{array}$} & \multicolumn{3}{|c|}{$\begin{array}{l}\text { Balkanla } \\
\mathbf{r}\end{array}$} & \multicolumn{3}{|c|}{ Diğer } \\
\hline \multicolumn{2}{|c|}{$\begin{array}{l}4 \\
\text { kişi }\end{array}$} & \multicolumn{2}{|c|}{43 kişi } & 5 kişi & \multicolumn{2}{|c|}{$\begin{array}{l}1 \\
\text { kişi }\end{array}$} & \multicolumn{2}{|c|}{27 kişi } & \multicolumn{2}{|c|}{$\begin{array}{l}8 \\
\text { kişi }\end{array}$} & \multicolumn{3}{|c|}{38 kişi } & \multicolumn{3}{|c|}{11 kişi } & \multicolumn{3}{|c|}{3 kişi } \\
\hline \multicolumn{7}{|c|}{ Sakal-Bıyık } & \multicolumn{13}{|c|}{ İsim } \\
\hline 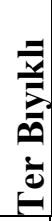 & $\frac{0}{\frac{0}{6}}$ & 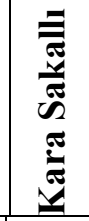 & 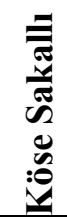 & 哥 & ¿ & 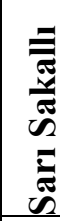 & 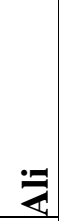 & 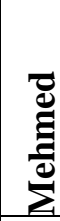 & 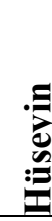 & 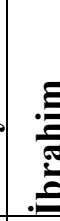 & 跑 & 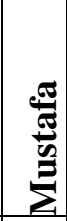 & 픞 & 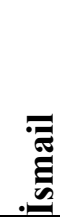 & 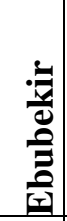 & 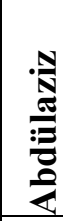 & 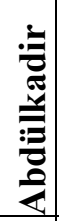 & $\underset{\Xi}{E}$ & : \\
\hline 4 & 17 & 6 & 1 & 14 & 3 & 2 & 9 & 6 & 5 & 4 & 4 & 4 & 3 & 3 & 2 & 1 & 1 & 1 & 1 \\
\hline
\end{tabular}

\section{Kalenderhâne Medresesi}

Fatih Sultan Mehmet'in İstanbul'u fethettikten sonra cami ve medreseye çevirdiği 8 kiliseden biridir. 1844 sayımında 56 kişi bulunmaktadır. 22 farklı isim 
kullanılmıştır. Mehmet ve Hüseyin en fazla kullanılan isimlerdir. Medresenin yaş ortalaması 23'tür. En yaşlı kişi 50, en küçük kişi ise 12 yaşındadır. Fizikî olarak 32 kişi orta, 3 kişi uzun boyludur. Medresede 15 oda bulunmaktadır. 1, 6, 15 numaralı odalar boştur. 2 kişi mülazımdır. 10 kişi Kastamonulu, 8 kişi Ezineli, 6 kişi Çankırılı, 5 kişi Karahisarlıdır. 1869 tarihli sayıma göre medresede toplam 45 kişi kayıtlıdır. 1914 raporuna göre zemini bitişik ve arka pencereleri olmadığından güneş ışığından ve temiz havadan mahrumdur. 15 odası olup ikisi büyük ve 2 kişilik odalardan oluşmaktadır. Bazı odalarında eşya vardır.

Tablo 18: Medrese-i Kalenderhâne Der-Kurb-1 Bozdoğan Kemeri’ne Kayıtlı Olan Kişilerin Genel Özellikleri

\begin{tabular}{|c|c|c|c|c|c|c|c|c|c|c|c|c|c|c|c|c|c|c|c|}
\hline & & & & & & & & & & & & & & & & & & & \\
\hline & & I aş A & ralı & & & & & Вo & & & & & & & [em] & eke & & & \\
\hline $0-14$ & & $15-3$ & & $40 \mathrm{v}$ & & $\mathbf{K}$ & & Ort & & $\begin{array}{l}\text { Uzt } \\
\text { n }\end{array}$ & & $\begin{array}{l}\text { Ana } \\
\text { u }\end{array}$ & & & alka & & & 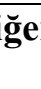 & \\
\hline $5 \mathrm{ki}$ & & $46 \mathrm{ki}$ & & $5 \mathrm{kis}$ & & - & & $32 \mathrm{k}$ & & $\begin{array}{l}3 \\
\text { kissi }\end{array}$ & & 521 & & & kişi & & & --. & \\
\hline & & Sak & al-B & Blyık & & & & & & & & & sim & & & & & & \\
\hline 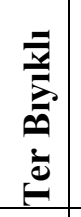 & 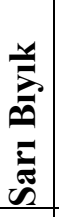 & $\frac{0}{2}$ & 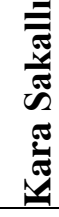 & 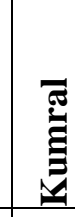 & $\bar{e}^{\bar{e}}$ & $\begin{array}{c}\bar{E} \\
\bar{E} \\
\bar{E} \\
\bar{E}\end{array}$ & $\frac{\vec{d}}{\stackrel{\Xi}{d}}$ & 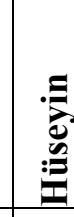 & 莺 & 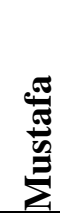 & 疍 & 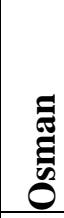 & قٍِ. & 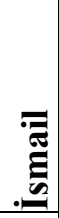 & : & 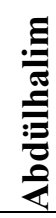 & $\gtreqless$ & & $\underset{\underline{E}}{\bar{E}}$ \\
\hline 2 & 1 & $\begin{array}{l}1 \\
7 \\
\end{array}$ & $\begin{array}{l}1 \\
4\end{array}$ & 9 & 7 & 1 & $\begin{array}{l}1 \\
2\end{array}$ & 8 & 6 & 6 & 3 & 3 & 2 & 2 & 1 & 1 & 1 & 1 & 1 \\
\hline
\end{tabular}

\section{Hasan Ağa Dâr-ül-Hadis Medresesi}

Bozdoğan Kemeri yakınlarındadır. Hasan Ağa tarafından 1707'de yaptırılmıştır. 1 fevkanî mescid, 9 tahtanî oda ve müştemilattan oluşmaktadır. 1844 sayımına göre 31 kişi bulunmaktadır. 11 farklı isim kullanılmıştır. Hasan, Ahmet, Mehmet en fazla kullanılan isimlerdir. Medresenin yaş ortalaması 24'tür. En büyük yaş 50, en küçük yaş ise 11'dir. Fizikî evsaf olarak 23 kişi orta, bir kişi uzun boyludur. Medresede 9 oda bulunmaktadır. 1 ve 3 numaralı odalar boştur. 1 kişi mülazımdır. 10 kişi Zileli, 4 kişi Ürgüplü, 3 kişi Bileciklidir. 1869 tarihli sayımda medresede toplamda 38 kişi kayıtlıdır. 
Tablo 19: Medrese-i Dâr-ül Hadis-i Hasan Ağa Kurb-1 Bozdoğan Kemeri’ne Kayıtlı Olan Kişilerin Genel Özellikleri

\begin{tabular}{|c|c|c|c|c|c|c|c|c|c|c|c|c|c|c|c|}
\hline \multicolumn{5}{|c|}{ Yaş Aralığı } & \multicolumn{4}{|c|}{ Boy } & \multicolumn{7}{|c|}{ Memleket } \\
\hline $0-14$ & \multicolumn{2}{|c|}{ 15-39 } & \multicolumn{2}{|c|}{\begin{tabular}{|ll}
40 & ve \\
+ & \\
\end{tabular}} & Kisa & \multicolumn{2}{|c|}{ Orta } & $\begin{array}{l}\text { Uzu } \\
\text { n }\end{array}$ & \multicolumn{2}{|c|}{$\begin{array}{l}\text { Anadol } \\
\text { u }\end{array}$} & \multicolumn{3}{|c|}{$\begin{array}{l}\text { Balkanla } \\
\mathbf{r}\end{array}$} & \multicolumn{2}{|c|}{ Diğer } \\
\hline 2 & \multicolumn{2}{|c|}{28 kişi } & \multicolumn{2}{|c|}{1 kişi } & ---- & \multicolumn{2}{|c|}{23 kişi } & 1 & \multicolumn{2}{|c|}{28 kişi } & \multicolumn{3}{|c|}{3 kişi } & \multicolumn{2}{|l|}{---- } \\
\hline \multicolumn{5}{|c|}{ Sakal-Bıyık } & \multicolumn{11}{|c|}{ İsim } \\
\hline 竧 & 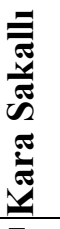 & 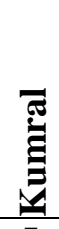 & 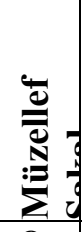 & 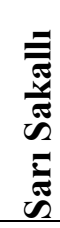 & 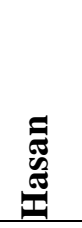 & 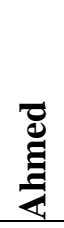 & 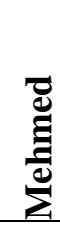 & $\frac{\stackrel{\pi}{\pi}}{\stackrel{\pi}{\pi}}$ & : & 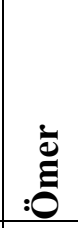 & 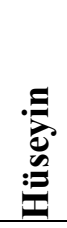 & 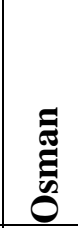 & 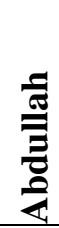 & 㢺 & 荵 \\
\hline 5 & 7 & 5 & 8 & 2 & 5 & 4 & 4 & 4 & 4 & 3 & 2 & 2 & 1 & 1 & 1 \\
\hline
\end{tabular}

\section{Kuyucu Murad Paşa Medresesi}

Medrese, Sultan I. Ahmet dönemi sadrazamlarından Kuyucu Murad Paşa tarafından yaptırılmıştır. 1792 yılında yapılan sayımda 16 talebe kayıtlıdır. 1844 yılı sayımında 48 kişi kayıtlıdır. 17 farklı isim kullanılmıştır. Mehmet, Mustafa, Ahmet en fazla kullanılan isimlerdir. Medresenin yaş ortalaması 25'tir. En yaşlı kişi 90, en küçük kişi 11 yaşındadır. Fizikî özellik olarak 2 kişi kısa, 20 kişi orta, 3 kişi uzun boyludur. 8 oda bulunmaktadır. 1,2 ve 4 numaralı odalar boştur. 1 kişi mülazım, 1 kişi de bevvabdır. 11 kişi Konyalı, 3 kişi Çarşambalı, 3 kişi Seferihisarlıdır. 1869 sayımına göre 46 kişi mevcuttur. Günümüzde İstanbul Üniversitesi Güzel Sanatlar Bölümü binası olarak kullanılmaktadır.

Tablo 20: Medrese-i Kuyucu Murad Paşa Kurb-1 Vezneciler’e Kayıtlı Olan Kişilerin Genel Özellikleri

\begin{tabular}{|c|c|c|c|c|c|c|c|c|c|c|c|c|c|c|c|c|c|c|c|c|}
\hline \multicolumn{6}{|c|}{ Yaş Aralığı } & \multicolumn{6}{|c|}{ Boy } & \multicolumn{9}{|c|}{ Memleket } \\
\hline \multicolumn{2}{|c|}{ 0-14 } & \multicolumn{2}{|c|}{$15-39$} & \multicolumn{2}{|c|}{$\begin{array}{ll}40 & \text { ve } \\
+ & \\
\end{array}$} & \multicolumn{2}{|l|}{ Kisa } & \multicolumn{2}{|c|}{ Orta } & \multicolumn{2}{|c|}{ Uzun } & \multicolumn{3}{|c|}{$\begin{array}{l}\text { Anadol } \\
\text { u }\end{array}$} & \multicolumn{3}{|c|}{$\begin{array}{l}\text { Balkanla } \\
\text { r }\end{array}$} & \multicolumn{3}{|c|}{ Diğer } \\
\hline \multicolumn{2}{|l|}{$\begin{array}{l}2 \\
\text { kiși }\end{array}$} & \multicolumn{2}{|c|}{42 kişi } & \multicolumn{2}{|c|}{4 kişi } & \multicolumn{2}{|c|}{2 kişi } & \multicolumn{2}{|c|}{20 kişi } & \multicolumn{2}{|c|}{3 kişi } & \multicolumn{3}{|c|}{40 kişi } & \multicolumn{3}{|c|}{3 kişi } & \multicolumn{3}{|c|}{4 kişi } \\
\hline \multicolumn{9}{|c|}{ Sakal-Bıyık } & \multicolumn{12}{|c|}{ İsim } \\
\hline 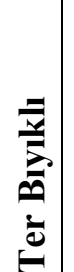 & $\frac{0}{2}$ & 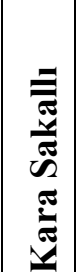 & 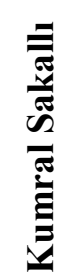 & 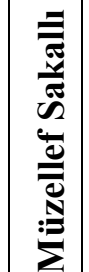 & 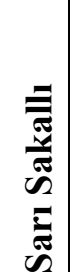 & 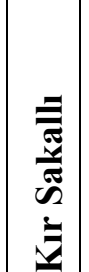 & 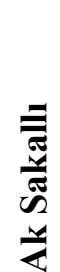 & 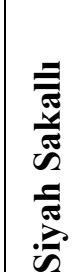 & 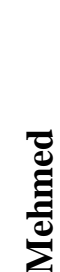 & 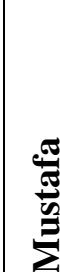 & 离 & : $\overline{\tilde{\pi}}$ & $=$ & 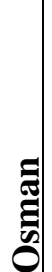 & $\begin{array}{l}\vec{a} \\
\overline{\mathbf{n}} \\
\overline{\mathbf{z}} \\
\bar{q}\end{array}$ & 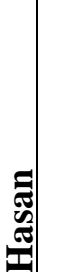 & 资: & $\overline{\bar{x}}$ & 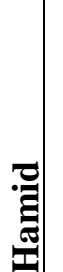 & כ. \\
\hline 1 & 9 & 9 & $\begin{array}{l}1 \\
1\end{array}$ & $\begin{array}{l}1 \\
1\end{array}$ & 3 & 1 & 1 & 1 & $\begin{array}{l}1 \\
\mathbf{3}\end{array}$ & 6 & 5 & 4 & 3 & 3 & 2 & 2 & 2 & 1 & 1 & 1 \\
\hline
\end{tabular}




\section{Damad İbrahim Paşa Medresesi}

1844 sayımına göre medresede 50 kişi kayıtlıdır. 20 farklı isim kullanılmıştır. Mehmet, Ahmet, Mustafa en fazla kullanılan isimlerdir. Medresenin yaş ortalaması 23 'tür. En yaşlı kişi 80, en küçük kişi 9 yaşındadır. Fizikî özellik olarak 4 kişi kısa, 29 kişi orta, 2 kişi uzun boyludur. Toplamda 14 odası vardır. 7, 9, 12 numaralı odalar boştur. 1 kişi mülazımdır. 7 kişi Akşehirli, 4 kişi Kastamonulu, 3 kişi Harputlu, 3 kişi Ünyelidir.

Tablo 21: Medrese-i Damad İbrahim Paşa Kurb-1 Şehzâde'ye Kayıtlı Olan Kişilerin Genel Özellikleri

\begin{tabular}{|c|c|c|c|c|c|c|c|c|c|c|c|c|c|c|c|c|c|c|c|c|c|c|c|c|}
\hline \multicolumn{7}{|c|}{ Yaş Aralığı } & \multicolumn{7}{|c|}{ Boy } & \multicolumn{11}{|c|}{ Memleket } \\
\hline \multicolumn{2}{|c|}{$0-14$} & \multicolumn{3}{|c|}{ 15-39 } & \multicolumn{2}{|c|}{$\begin{array}{l}40 \text { ve } \\
+\quad\end{array}$} & \multicolumn{3}{|c|}{ Kisa } & \multicolumn{2}{|c|}{ Orta } & \multicolumn{2}{|c|}{$\begin{array}{l}\text { Uzu } \\
\text { n }\end{array}$} & \multicolumn{3}{|c|}{$\begin{array}{l}\text { Anadol } \\
\text { u }\end{array}$} & \multicolumn{4}{|c|}{$\begin{array}{l}\text { Balkanla } \\
\mathbf{r}\end{array}$} & \multicolumn{4}{|c|}{ Diğer } \\
\hline \multicolumn{2}{|c|}{$\begin{array}{l}5 \\
\text { kişi }\end{array}$} & \multicolumn{3}{|c|}{42 kişi } & \multicolumn{2}{|c|}{3 kişi } & \multicolumn{3}{|c|}{$\begin{array}{l}4 \\
\text { kişi }\end{array}$} & \multicolumn{2}{|c|}{29 kişi } & \multicolumn{2}{|c|}{$\begin{array}{l}2 \\
\text { kişi }\end{array}$} & \multicolumn{3}{|c|}{41 kişi } & \multicolumn{4}{|c|}{5 kişi } & \multicolumn{4}{|c|}{2 kişi } \\
\hline \multicolumn{10}{|c|}{ Sakal-Bıyık } & \multicolumn{15}{|c|}{ İsim } \\
\hline & $\frac{2}{2}$ & 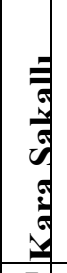 & 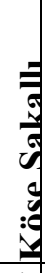 & 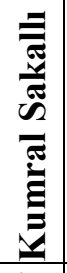 & 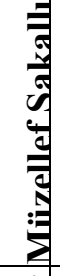 & 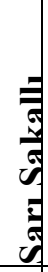 & 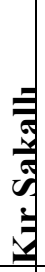 & 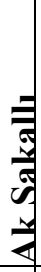 & 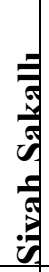 & 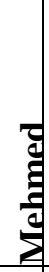 & 市 & $\frac{\frac{\pi}{6}}{\frac{\pi}{V}}$ & 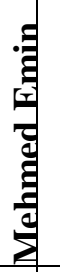 & & 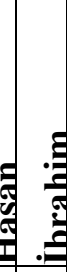 & 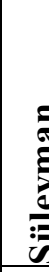 & & $=$ & 青 & 跑 & 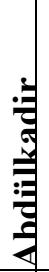 & & & \\
\hline 1 & $\begin{array}{l}1 \\
7\end{array}$ & 5 & 1 & 1 & 6 & 3 & 2 & 1 & 1 & 9 & 6 & 5 & 4 & 3 & 3 & 3 & 2 & 2 & 1 & 1 & 1 & 1 & 1 & 1 \\
\hline
\end{tabular}

\section{Ebu'l-Fâzıl Mahmud Efendi Medresesi}

1844 sayımında medresede 38 kişi bulunmaktadır. 19 farklı isim kullanılmıştır. Ahmet, Hasan, Hüseyin, Mustafa en fazla kullanılan isimlerdir. Medresenin yaş ortalaması 25'tir. En yaşlı kişi 40, en küçük kişi ise 12 yaşındadır. Fizikî özellik olarak 18 kişi orta, 6 kişi uzun boyludur. Medresede 11 oda vardır. 2 ve 9 numaralı odalar boştur. 1 kişi mülazım ve 1 kişi de bevvabdır. 3 kişi Tırnovalıdır. Kütahya, Göynük, Safranbolu, Çankırı, Pazarcıklı 2'şer kişi vardır. 1914 raporuna göre 11 odası, 1 dersanesi mevcuttur. Odalar haraptır. Çarşı ortasında kaldığı ve dar bir alana sıkıştığı için talebe iskânına uygun değildir. 
Tablo 22: Medrese-i Ebu'l-Fâzıl Mahmud Efendi Kurb-1 Şehzâde’ye Kayıtlı Olan Kişilerin Genel Özellikleri

\begin{tabular}{|c|c|c|c|c|c|c|c|c|c|c|c|c|c|c|c|c|c|c|c|c|c|c|c|c|}
\hline \multicolumn{6}{|c|}{ Yaș Aralığı } & \multicolumn{8}{|c|}{ Boy } & \multicolumn{11}{|c|}{ Memleket } \\
\hline $0-14$ & \multicolumn{3}{|c|}{\begin{tabular}{|c|}
$15-39$ \\
\end{tabular}} & \multicolumn{2}{|c|}{$\begin{array}{ll}40 & \text { ve } \\
+ & \end{array}$} & \multicolumn{3}{|c|}{ Kisa } & \multicolumn{2}{|c|}{ Orta } & & \multicolumn{2}{|c|}{$\begin{array}{l}\text { Uzu } \\
\text { n }\end{array}$} & \multicolumn{3}{|c|}{$\begin{array}{l}\text { Anadol } \\
\text { u }\end{array}$} & \multicolumn{4}{|c|}{$\begin{array}{l}\text { Balkanla } \\
\mathbf{r}\end{array}$} & \multicolumn{4}{|c|}{ Diğer } \\
\hline $\begin{array}{l}3 \\
\text { kişi }\end{array}$ & \multicolumn{3}{|c|}{34 kişi } & \multicolumn{2}{|c|}{1 kişi } & \multicolumn{3}{|c|}{---- } & \multicolumn{3}{|c|}{18 kişi } & \multicolumn{2}{|c|}{$\begin{array}{l}6 \\
\text { kiși }\end{array}$} & \multicolumn{3}{|c|}{23 kişi } & \multicolumn{4}{|c|}{8 kişi } & \multicolumn{4}{|c|}{7 kişi } \\
\hline \multicolumn{6}{|c|}{ Sakal-Bıyık } & \multicolumn{19}{|c|}{ İsim } \\
\hline 武 & $\begin{array}{l}5 \\
5 \\
5 \\
5 \\
7 \\
7 \\
7\end{array}$ & 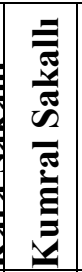 & 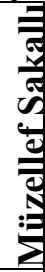 & 霝 & & 过 & 菤 & 哥 & 柔 & & 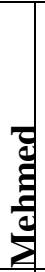 & हี & & 馬 & 월 & $\frac{\sigma}{\bar{G}}$ & 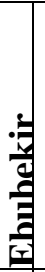 & : & & 司 & & 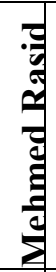 & & 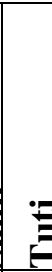 \\
\hline \begin{tabular}{l|l}
2 & 6
\end{tabular} & 6 & $\begin{array}{l}1 \\
3\end{array}$ & 4 & 5 & 1 & 4 & 4 & 4 & 4 & 3 & 3 & 3 & 2 & 1 & 1 & 1 & 1 & 1 & 1 & 1 & 1 & 1 & 1 & 1 \\
\hline
\end{tabular}

\section{Mimar Kasım Medresesi}

1844 sayımına göre 42 kişi kayıtlıdır. 24 farklı isim kullanılmıştır. Mehmet, Salih, Mustafa en fazla kullanılan isimlerdir. Medresenin yaş ortalaması 22'dir. En yaşlı kişi 40, en küçük kişi 12 yaşındadır. Fizikî özellik olarak 1 kişi kısa, 15 kişi orta, 6 kişide uzun boyludur. 10 odası vardır. 3, 4, 5, 7 numaralı odalar boştur. 1 kişi mülazımdır. 17 kişi Bosnalıdır. 1869 tarihli sayıma göre medresede toplamda 18 kişi kayıtlıdır. 1914 raporuna göre zemine bitişik güneş ışı̆̆1 ve temiz hava alamayan 12 odası vardır. Genel itibariyle müştemilatı harap olduğundan ve çevresi yüksek binalarla kaplandığından kesinlikle talebe iskânına uygun değildir. 5 kişi dışarıdan olmakla beraber 20 talebesi vardır.

Tablo 23: Medrese-i Mimar Kasım Der-Kurb-1 Câmi 'i Şehzâde’ye Kayıtlı Olan Kişilerin Genel Özellikleri

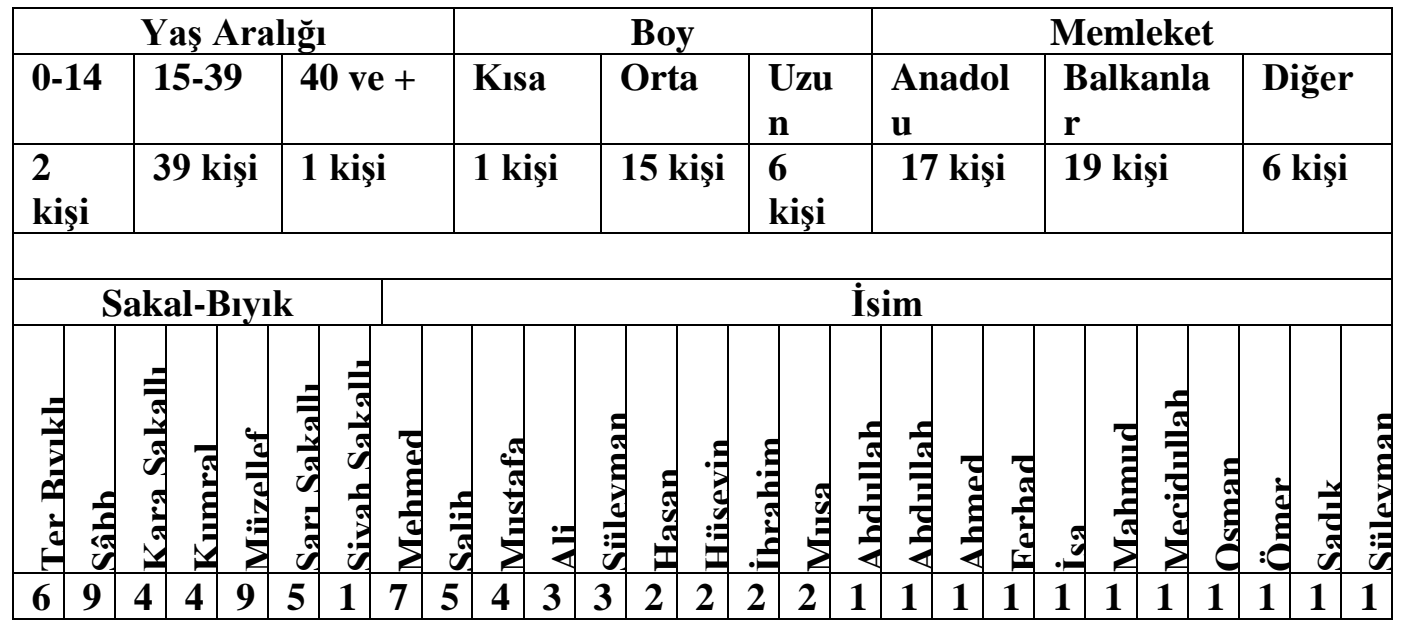




\section{Ankaravî İsmail Efendi Medresesi}

1844 sayımında 50 kişi vardır. 24 farklı isim kullanılmıştır. Mehmet, Ahmet ve Ali en fazla kullanılan isimlerdir. 5 kişi çift isimlidir. Medresenin yaş ortalaması 23'tür. En yaşlıkişi 57, en küçük kişi ise 12 yaşındadır. Fizikî özellik olarak 2 kişi kısa, 31 kişi orta, 1 kişi uzun boyludur. Sıralı olarak 13 odası vardır. 1, 4, 5, 6 numaralı odalar dolu olup diğerleri boştur. 1 mülazım, 1 bevvab, 1 kişide hattat olarak bulunmaktadır. 10 kişi Düzceli, 5 kişi İçelli, 4 kişi Üsküplüdür. 1869 tarihli sayımda medresede toplamda 27 kişi kayıtlıdır. 1914 raporuna göre 13 hücresi vardır. 1 odası zeminden yüksekçedir. 1 baraka ilave edilmiştir. Tamire muhtaç olduğundan ilim yapmaya uygun değildir. Tamir edildikten sonra ilim yapmaya uygun hale getirilebilir. 15 kişi ikamet edebilir. Sonradan eklenen barakayla birlikte toplam 14 odası vardır. 1918 de ordu dairesi birinci sevk taburu tarafından işgal edilmiştir.

Tablo: 24: Medrese-i Ankaravî İsmail Efendi Kurb-1 Şehzâde’ye Kayıtlı Olan Kişilerin Genel Özellikleri

\begin{tabular}{|c|c|c|c|c|c|c|c|c|c|c|c|c|c|c|c|c|c|}
\hline \multicolumn{5}{|c|}{ Yaş Aralığı } & \multicolumn{5}{|c|}{ Boy } & \multicolumn{8}{|c|}{ Memleket } \\
\hline $0-1$ & & $5-39$ & \multicolumn{2}{|c|}{$\begin{array}{ll}40 & v e \\
+ & \end{array}$} & Kisa & & rta & \multicolumn{2}{|c|}{$\begin{array}{l}\text { Uzu } \\
\text { n }\end{array}$} & \multicolumn{2}{|c|}{$\begin{array}{l}\text { Anadol } \\
\text { u }\end{array}$} & \multicolumn{3}{|c|}{$\begin{array}{l}\text { Balkanla } \\
\mathbf{r}\end{array}$} & \multicolumn{3}{|c|}{ Diğer } \\
\hline $\begin{array}{l}6 \\
\text { kişi }\end{array}$ & \multicolumn{2}{|c|}{41 kişi } & \multicolumn{2}{|c|}{3 kişi } & $\begin{array}{l}2 \\
\text { kişi }\end{array}$ & \multicolumn{2}{|c|}{31 kişi } & & \multicolumn{2}{|c|}{36 kişi } & \multicolumn{3}{|c|}{11 kişi } & \multicolumn{3}{|c|}{2 kişi } \\
\hline \multicolumn{8}{|c|}{ Sakal-Bıyık } & \multicolumn{10}{|c|}{ İsim } \\
\hline 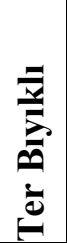 & $\frac{0}{6}$ & 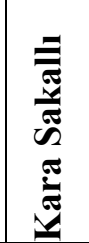 & 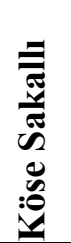 & 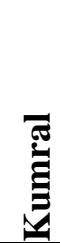 & ? & 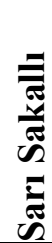 & 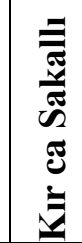 & 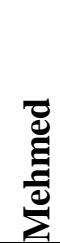 & 总 & 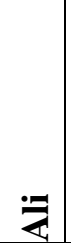 & 플 & 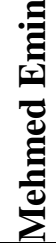 & 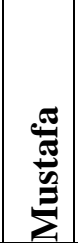 & 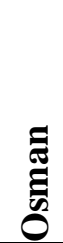 & 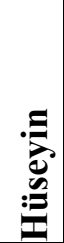 & $\stackrel{\square}{\Xi}$ & : \\
\hline 3 & 13 & 13 & 1 & 7 & 5 & 3 & 1 & 7 & 6 & 6 & 3 & 3 & 3 & 3 & 2 & 2 & 1 \\
\hline
\end{tabular}

\section{Baba Mahmud Ebubekir Efendi Medresesi}

1844 sayımına göre medresede 24 kişi kayıtlıdır. 11 farklı isim kullanılmıştır. Bir kişi çift isimlidir. En fazla kullanılan isim Mehmet'tir. Medresenin yaş ortalaması 25 'tir. En yaşlı kişi 45, en küçük kişi ise 14 yaşındadır. Fizikî özellik olarak 10 kişi orta, 6 kişi uzun boyludur. Medresede 7 oda bulunmaktadır. 1 kişi mülazımdır. 4 kişi Karaağaçlı, 3 kişi Ankaralıdır. 
Tablo 25: Medrese-i Baba Mahmud Ebubekir Efendi Kurb-1 Şehzâde’ye Kayıtlı Olan Kişilerin Genel Özellikleri

\begin{tabular}{|c|c|c|c|c|c|c|c|c|c|c|c|c|c|c|c|c|}
\hline \multicolumn{5}{|c|}{ Yaş Aralığı } & \multicolumn{5}{|c|}{ Boy } & \multicolumn{7}{|c|}{ Memleket } \\
\hline $0-14$ & & 15-39 & \multicolumn{2}{|c|}{$\begin{array}{ll}40 & \text { ve } \\
+ & \end{array}$} & \multicolumn{2}{|c|}{ Kisa } & \multicolumn{2}{|c|}{ Orta } & $\begin{array}{l}\text { Uzu } \\
\text { n }\end{array}$ & \multicolumn{2}{|c|}{$\begin{array}{l}\text { Anadol } \\
\text { u }\end{array}$} & \multicolumn{3}{|c|}{$\begin{array}{l}\text { Balkanla } \\
\mathbf{r}\end{array}$} & \multicolumn{2}{|c|}{ Diğer } \\
\hline \multicolumn{2}{|c|}{1 kişi } & 22 kiş & \multicolumn{2}{|c|}{1 kişi } & \multicolumn{2}{|c|}{---- } & \multicolumn{2}{|c|}{10 kişi } & $\begin{array}{l}6 \\
\text { kiși }\end{array}$ & \multicolumn{2}{|c|}{15 kişi } & \multicolumn{3}{|c|}{5 kişi } & \multicolumn{2}{|c|}{4 kişi } \\
\hline \multicolumn{6}{|c|}{ Sakal-Bıyık } & \multicolumn{11}{|c|}{ İsim } \\
\hline 㐫 & $\frac{0}{2}$ & 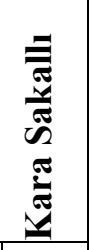 & 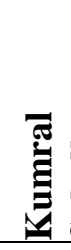 & 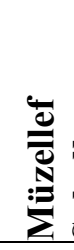 & 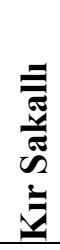 & 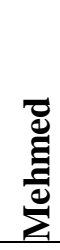 & 플 & 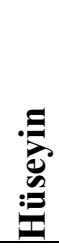 & 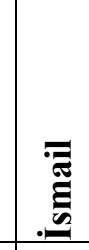 & 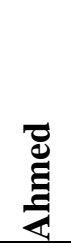 & $\gtreqless$ & Uై & 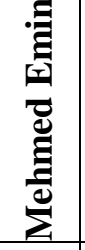 & 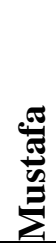 & 宽 & $\underset{\mathscr{E}}{Z}$ \\
\hline 1 & 5 & 9 & 5 & 3 & 1 & 11 & 2 & 2 & 2 & 1 & 1 & 1 & 1 & 1 & 1 & 1 \\
\hline
\end{tabular}

\section{Gazanfer Ağa Medresesi}

Sultan III. Murat ve III. Mehmet devirlerinde Hasodabaşı olarak vazife gören Gazanfer Ağa tarafindan yaptırılmıştır. 1792 yılında yapılan sayımda medresede 16 kişi vardır. 1844 sayımında medresede 44 kişi kayıtlıdır. 22 farklı isim kullanılmıştır. 3 kişi çift isimlidir. Mehmet, Ali, Hüseyin en fazla kullanılan isimlerdir. Medresenin yaş ortalaması 24'tür. En yaşlı kişi 35, en küçük kişi ise 13 yaşındadır. Fizikî özellik olarak 25 kişi orta, 6 kişi uzun boyludur. Medresede 14 oda vardır. 3, 4, 10, 11 numaralı odalar boştur. 1 bevvab, 2 mülazım vardır. 10 kişi Bosnalı, 6 kişi Şumnulu, 3 kişi Trabzonludur. 1869 sayımında 23 talebe kayıtlıdır. 1914 raporunda ise 30 kişinin ikamet edebileceği belirtilmiştir.

Tablo 26: Medrese-i Gazanfer Ağa Kurb-1 Kırkçeşme’ye Kayıtlı Olan Kişilerin Genel Özellikleri

\begin{tabular}{|c|c|c|c|c|c|c|c|c|c|c|c|c|c|c|c|c|c|}
\hline \multicolumn{6}{|c|}{ Yaş Aralığı } & \multicolumn{5}{|c|}{ Boy } & \multicolumn{7}{|c|}{ Memleket } \\
\hline \multicolumn{2}{|c|}{$0-14$} & \multicolumn{2}{|c|}{$15-39$} & \multicolumn{2}{|c|}{40 ve +} & Kisa & \multicolumn{2}{|c|}{ Orta } & \multicolumn{2}{|c|}{$\begin{array}{l}\text { Uzu } \\
\text { n }\end{array}$} & \multicolumn{2}{|c|}{$\begin{array}{l}\text { Anadol } \\
\text { u }\end{array}$} & \multicolumn{3}{|c|}{\begin{tabular}{|l|} 
Balkanla \\
$\mathbf{r}$
\end{tabular}} & \multicolumn{2}{|c|}{ Diğer } \\
\hline \multicolumn{2}{|c|}{3 kişi } & \multicolumn{2}{|c|}{$\begin{array}{l}41 \\
\text { kişi }\end{array}$} & \multicolumn{2}{|l|}{----} & ---- & \multicolumn{2}{|c|}{25 kişi } & \multicolumn{2}{|c|}{$\begin{array}{l}6 \\
\text { kişi }\end{array}$} & \multicolumn{2}{|c|}{17 kişi } & \multicolumn{3}{|c|}{20 kişi } & \multicolumn{2}{|c|}{4 kişi } \\
\hline \multicolumn{9}{|c|}{ Sakal-Bıylk } & \multicolumn{9}{|c|}{ İsim } \\
\hline 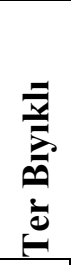 & 曾 & 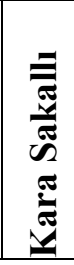 & 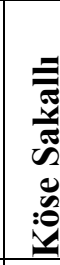 & 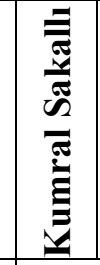 & 式 & 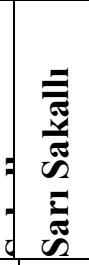 & 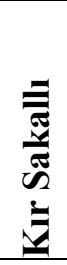 & 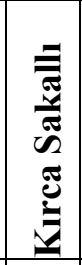 & 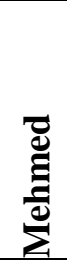 & $\frac{1}{4}$ & 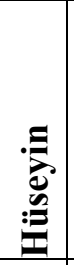 & 臟 & $\begin{array}{l}\tilde{T} \\
\text { : } \\
\text { О }\end{array}$ & 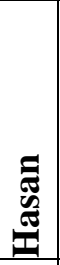 & 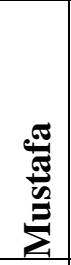 & 苛 & $\underset{E}{\mathbb{E}}$ \\
\hline 5 & 8 & 5 & 1 & 10 & 4 & 6 & 2 & 1 & 7 & 5 & 4 & 3 & 3 & 3 & 2 & 2 & 2 \\
\hline
\end{tabular}




\section{Amucazâde Hüseyin Paşa Medresesi}

Medrese, Köprülü ailesinden Amucazade Hüseyin Paşa tarafından Dârü'l-hadis olarak yaptırılmıştır. 1792 sayımında 18 kişi vardır. 1844 sayımında medresede 36 kişi mevcuttur. 26 farklı isim kullanılmıştır. Selim, Ahmet, Ali en fazla kullanılan isimlerdir. Medresenin yaş ortalaması 26'dır. En yaşlı kişi 50, en küçük kişi ise 13 yaşındadır. Fizikî evsaf olarak 4 kişi kısa, 18 kişi orta, 10 kişi uzun boyludur. Toplamda 18 odası vardır. 3, 6, 10, 13 numaralı odalar boştur. 1 bevvab ve 2 mülazım vardır. 1869 da yapılan sayımda 58 talebe ders görmektedir. 1914 raporuna göre medrese hücrelerinin talebelere yetersiz gelmesi sebebiyle bazı talebeler, bahçeye yapılan 10 kadar barakada kalmaktadır. 1967'den itibaren Türk İnşaat ve Sanat Eserleri Müzesi olarak kullanılmaktadır.

Tablo 27: Medrese-i Amucazâde Hüseyin Paşa İçhan’a Kayıtlı Olan Kişilerin Genel Özellikleri

\begin{tabular}{|c|c|c|c|c|c|c|c|c|c|c|c|c|c|c|c|c|c|}
\hline \multicolumn{6}{|c|}{ Yaş Aralığı } & \multicolumn{5}{|c|}{ Boy } & \multicolumn{7}{|c|}{ Mleket } \\
\hline $0-1$ & \multicolumn{3}{|c|}{$15-39$} & \multicolumn{2}{|c|}{40 ve +} & Kisa & \multicolumn{2}{|c|}{ Orta } & \multicolumn{2}{|c|}{ Uzun } & \multicolumn{2}{|c|}{$\begin{array}{l}\text { Anadol } \\
\text { u }\end{array}$} & \multicolumn{3}{|c|}{$\begin{array}{l}\text { Balkanla } \\
\text { r }\end{array}$} & \multicolumn{2}{|l|}{ Diğer } \\
\hline $\begin{array}{l}1 \\
\text { kişi }\end{array}$ & \multicolumn{3}{|c|}{29 kişi } & \multicolumn{2}{|c|}{6 kişi } & 4 kişi & \multicolumn{2}{|c|}{$\begin{array}{l}18 \\
\text { kişi }\end{array}$} & \multicolumn{2}{|c|}{10 kişi } & \multicolumn{2}{|c|}{19 kişi } & \multicolumn{3}{|c|}{9 kişi } & \multicolumn{2}{|l|}{7 kişi } \\
\hline \multicolumn{7}{|c|}{ Sakal-Bıyık } & \multicolumn{11}{|c|}{ İsim } \\
\hline$\frac{0}{\frac{1}{6}}$ & 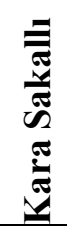 & 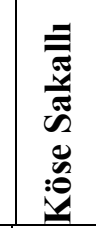 & 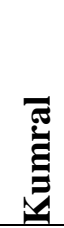 & 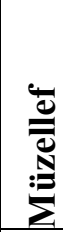 & 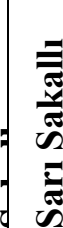 & 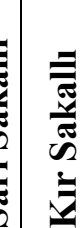 & 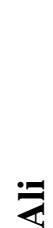 & 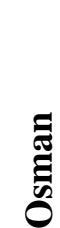 & 害 & 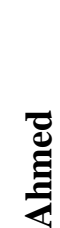 & : & 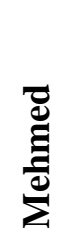 & $\frac{\text { Ded }}{\text { E }}$ & 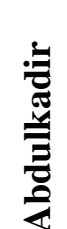 & 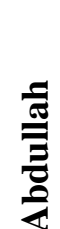 & 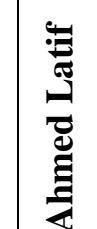 & 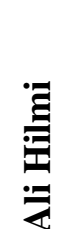 \\
\hline 4 & $\overline{12}$ & 1 & 9 & 3 & 5 & 1 & 3 & 3 & 3 & 2 & 2 & 2 & 2 & 1 & 1 & 1 & 1 \\
\hline
\end{tabular}

\section{Dülgerzâde Medresesi}

Medresede 1844 sayımında 18 kişi vardır. 13 farklı isim kullanılmıştır. Mehmet, Numan, Salih en fazla kullanılan isimlerdir. Medresenin yaş ortalaması 25'tir. En yaşlı kişi 35 yaşında, en küçük kişi ise 20 yaşındadır. Fizikî özellik olarak 13 kişi orta, 1 kişi uzun boyludur. Medresede 5 oda vardır. 1 ve 2 numaralı odalar boştur. 1 kişi mülazımdır. 10 kişi Bosnalıdır. 
Tablo 28: Medrese-i Dülgerzâde’ye Kayıtlı Olan Kişilerin Genel Özellikleri

\begin{tabular}{|c|c|c|c|c|c|c|c|c|c|c|c|c|c|c|c|c|c|c|}
\hline \multicolumn{6}{|c|}{ Yaş Aralığı } & \multicolumn{6}{|c|}{ Boy } & \multicolumn{7}{|c|}{ Memleket } \\
\hline \multicolumn{2}{|c|}{\begin{tabular}{l|l|}
$0-14$ \\
\end{tabular}} & \multicolumn{2}{|c|}{$15-39$} & \multicolumn{2}{|c|}{$\begin{array}{l}40 \text { ve } \\
+\quad\end{array}$} & \multicolumn{2}{|c|}{ Kisa } & \multicolumn{2}{|c|}{ Orta } & \multicolumn{2}{|c|}{ Uzun } & \multicolumn{2}{|c|}{$\begin{array}{l}\text { Anadol } \\
\text { u }\end{array}$} & \multicolumn{3}{|c|}{\begin{tabular}{|l} 
Balkanla \\
$\mathbf{r}$
\end{tabular}} & \multicolumn{2}{|c|}{ Diğer } \\
\hline \multicolumn{2}{|c|}{---- } & \multicolumn{2}{|c|}{18 kişi } & \multicolumn{2}{|c|}{----- } & \multicolumn{2}{|c|}{$-\cdots$} & \multicolumn{2}{|c|}{13 kişi } & \multicolumn{2}{|c|}{1 kişi } & \multicolumn{2}{|c|}{4 kişi } & \multicolumn{3}{|c|}{12 kişi } & \multicolumn{2}{|c|}{2 kiși } \\
\hline \multicolumn{6}{|c|}{ Sakal-Bıyık } & \multicolumn{13}{|c|}{ İsim } \\
\hline 竔 & 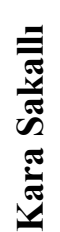 & 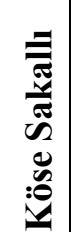 & 馬 & 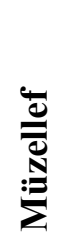 & 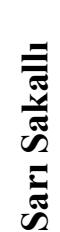 & 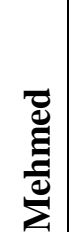 & 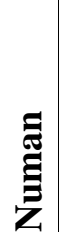 & 竭 & 总 & ; & 这 & 릍 & 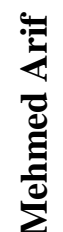 & 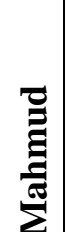 & 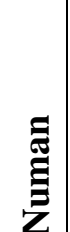 & $\begin{array}{l}\text { : } \\
\text { : } \\
\text { : }\end{array}$ & ప̈ & 苞 \\
\hline 3 & 4 & 1 & 4 & 3 & 3 & 4 & 2 & 2 & 1 & 1 & 1 & 1 & 1 & 1 & 1 & 1 & 1 & 1 \\
\hline
\end{tabular}

\section{Sultan Mehmed Han Feyzullah Efendi Medresesi}

Fatih’te Macar Kardeşler Caddesi üzerinde bugün Millet Kütüphanesi olarak kullanılan bina adını, Sultan Mustafa devrinde Şeyhülislamlık yapmış olan Feyzullah Efendi'den alır. XVII. asır Türk mimarisinin özelliklerini taşıyan medrese, klasik devrin son örneklerindendir. Toplamda 24 kişi kayıtlıdır. 1844 sayımında 24 kişi vardır. 11 farklı isim kullanılmıştır. Halil, Ahmet, Ali ve Osman en fazla kullanılan isimlerdir. Medresenin yaş ortalaması 22'dir. En yaşlı kişi 35, en küçük kişi 12 yaşındadır. Fizikî özellik olarak 2 kişi kısa, 15 kişi orta, 2 kişi uzun boyludur. Toplam 7 odası mevcuttur.

1, 4 ve 6 numaralı odalar boştur. 1 mülazım vardır. 8 kişi Bilecikli, 8 kişi ise Kuyucaklıdır. 1914 raporuna göre odaları zemine bitişiktir ve güneş ışığı almamaktadır. 10 adet odası olmakla beraber sonradan 5 baraka ilave edilmiştir. Talebe iskânına uygun değildir. Fakat yeniden inşa edilmesi halinde iskâna uygun hale gelebilir. 1918 de vakıflar müdürlüğü tarafından kütüphane olarak kullanılmıştır. 
Tablo 29: Medrese-i Feyzullah Efendi Kurb-1 Sultan Mehmed Han'a Kayıtlı Olan Kişilerin Genel Özellikleri

\begin{tabular}{|c|c|c|c|c|c|c|c|c|c|c|c|c|c|c|c|c|}
\hline \multicolumn{5}{|c|}{ Yaş Aralığı } & \multicolumn{5}{|c|}{ Boy } & \multicolumn{7}{|c|}{ Memleket } \\
\hline \multicolumn{2}{|c|}{$0-14$} & \multicolumn{2}{|c|}{$15-39$} & $\begin{array}{ll}40 & \text { ve } \\
+ & \\
\end{array}$ & \multicolumn{2}{|c|}{ Kisa } & \multicolumn{2}{|l|}{ Orta } & $\begin{array}{l}\text { Uzu } \\
\text { n }\end{array}$ & \multicolumn{2}{|c|}{$\begin{array}{l}\text { Anadol } \\
\text { u }\end{array}$} & \multicolumn{3}{|c|}{$\begin{array}{l}\text { Balkanla } \\
\mathbf{r}\end{array}$} & \multicolumn{2}{|c|}{ Diğer } \\
\hline \multicolumn{2}{|c|}{2 kişi } & 22 kişi & \multicolumn{2}{|c|}{$\begin{array}{l}---- \\
\end{array}$} & \multicolumn{2}{|c|}{$\begin{array}{l}2 \\
\text { kişi }\end{array}$} & \multicolumn{2}{|c|}{15 kişi } & $\begin{array}{l} \\
\text { kişi }\end{array}$ & \multicolumn{2}{|c|}{24 kişi } & \multicolumn{3}{|c|}{------ } & \multicolumn{2}{|c|}{---- } \\
\hline \multicolumn{6}{|c|}{ Sakal-Bıyık } & \multicolumn{11}{|c|}{ İsim } \\
\hline 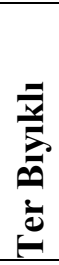 & $\frac{0}{\sum_{0}^{2}}$ & 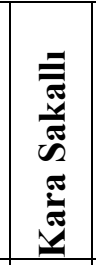 & 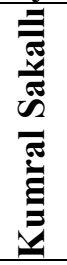 & 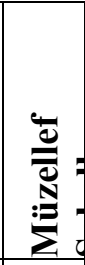 & 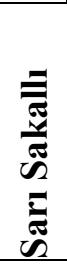 & : & 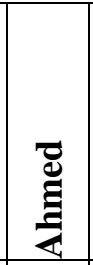 & 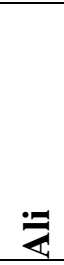 & $\frac{\stackrel{\sigma \pi}{\pi}}{\stackrel{5}{\mathscr{S}}}$ & 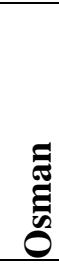 & 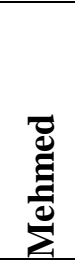 & 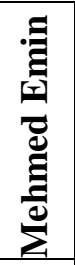 & 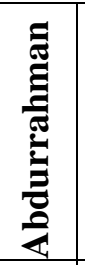 & 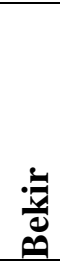 & 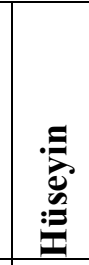 & $\frac{\text { Ze }}{\sum}$ \\
\hline 2 & 6 & 1 & $\overline{12}$ & 1 & 1 & 4 & 3 & 3 & 3 & 3 & 2 & 2 & 1 & 1 & 1 & 1 \\
\hline
\end{tabular}

\section{Pîrî Mehmed Paşa Medresesi}

1844 sayımında medresede 24 kişi mevcuttur. 12 farklı isim kullanılmıştır. Mehmet, Abdullah ve Ahmet en fazla kullanılan isimlerdir. Medresenin yaş ortalaması 26 'dır. En yaşlı olan kişi 60, en küçük kişi ise 15 yaşındadır. Fizikî özellik olarak 2 kişi kısa, 14 kişi orta, 3 kişi uzun boyludur. Toplamda 10 oda mevcuttur. 9 numaralı oda boştur. 1 kişi mülazımdır. 1869 tarihli sayımda medresede toplamda 40 kişi kayıtlıdır. 1914 raporuna göre odalar zemine bitişiktir. Bazı odalar ufak olup birer kişilik, bazı odalar ikişer kişiliktir. Cami ve mezarlık arasında olduğundan yeniden inşa edilip, iskâna uygun hale getirilebilir.

Tablo 30: Medrese-i Pîrî Mehmed Paşa Kurb-1 Zeyrek’e Kayıtlı Olan Kişilerin Genel Özellikleri

\begin{tabular}{|c|c|c|c|c|c|c|c|c|c|c|c|c|c|c|c|c|c|}
\hline \multicolumn{5}{|c|}{ Yaş Aralığı } & \multicolumn{5}{|c|}{ Boy } & \multicolumn{8}{|c|}{ Memleket } \\
\hline $0-1$ & & $5-39$ & \multicolumn{2}{|c|}{$\begin{array}{ll}40 \text { ve } \\
+\end{array}$} & \multicolumn{2}{|c|}{ Kisa } & \multicolumn{2}{|l|}{ Orta } & $\begin{array}{l}\text { Uzu } \\
\text { n }\end{array}$ & \multicolumn{2}{|c|}{$\begin{array}{l}\text { Anadol } \\
\text { u }\end{array}$} & \multicolumn{4}{|c|}{$\begin{array}{l}\text { Balkanla } \\
\mathbf{r}\end{array}$} & \multicolumn{2}{|c|}{ Diğer } \\
\hline$---\cdot$ & \multicolumn{2}{|c|}{23 kişi } & \multicolumn{2}{|c|}{1 kişi } & \multicolumn{2}{|c|}{$\begin{array}{l}2 \\
\text { kişi }\end{array}$} & \multicolumn{2}{|c|}{14 kişi } & & \multicolumn{2}{|c|}{17 kişi } & \multicolumn{4}{|c|}{1 kişi } & \multicolumn{2}{|c|}{4 kişi } \\
\hline \multicolumn{5}{|c|}{ Sakal-Bıyık } & \multicolumn{13}{|c|}{ İsim } \\
\hline$\frac{0}{2}$ & 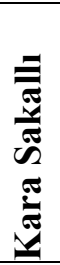 & 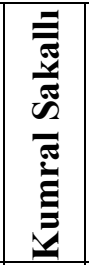 & 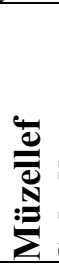 & 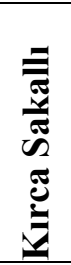 & 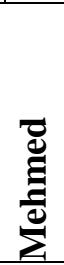 & 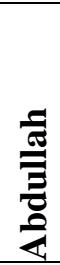 & 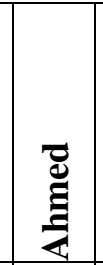 & 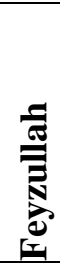 & 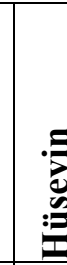 & & & & 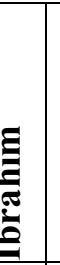 & 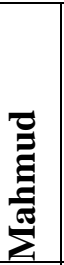 & 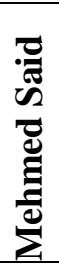 & : & 5 \\
\hline 2 & 5 & 8 & 2 & 1 & 6 & 3 & 3 & 3 & 2 & 1 & 1 & & & 1 & 1 & 1 & 1 \\
\hline
\end{tabular}




\section{Hamid Efendi Medresesi}

Zeyrek'te Unkapanı'na giderken sol taraftaki Fil Yokuşu üzerinde bulunan medrese, Bizans yapısı bir bina üzerine Ebusuud Efendi'nin halefi Şeyhülislam Hamid Efendi tarafından XVI. asrın ikinci yarısında Mimar Koca Sinan’a inşa ettirilmiştir. Medresede toplamda 30 kişi kayıtlıdır. 1 müderris vardır. 1844 yılı sayımında medresede 51 kişi bulunmaktadır. 23 farklı isim kullanılmıştır. Ahmet, Mustafa, Mehmet en fazla kullanılan isimlerdir. Medresede yaş ortalaması 21'dir. En yaşlı kişi 38, en küçük kişi ise 13 yaşındadır. Fizikî özellik olarak 7 kişi kısa, 14 kişi orta, 8 kişi uzun boyludur. Toplamda medresede 9 oda mevcuttur. 1914 raporuna göre medrese iki katlıdır. Toplamda 26 oda vardır. 3 ahşap oda ile birlikte 29 oda olmuştur. Avlusu geniş olmakla birlikte yeniden inşa edilirse ilme uygun hale gelebilir. 40 kişi ikamet edebilir. 1918 de bir kısmına muhacirler yerleşmiştir.

Tablo: 31: Medrese-i Hamid Efendi Kurb-1 Zeyrek’e Kayıtlı Olan Kişilerin Genel Özellikleri

\begin{tabular}{|c|c|c|c|c|c|c|c|c|c|c|c|c|c|c|c|c|c|c|c|}
\hline \multicolumn{6}{|c|}{ Yaş Aralığı } & \multicolumn{6}{|c|}{ Boy } & \multicolumn{8}{|c|}{ Memleket } \\
\hline $0-14$ & \multicolumn{3}{|c|}{ 15-39 } & \multicolumn{2}{|c|}{$\begin{array}{ll}40 & \text { ve } \\
+ & \\
\end{array}$} & \multicolumn{2}{|c|}{ Kisa } & \multicolumn{2}{|c|}{ Orta } & \multicolumn{2}{|c|}{ Uzun } & \multicolumn{2}{|c|}{$\begin{array}{l}\text { Anadol } \\
\text { u }\end{array}$} & \multicolumn{3}{|c|}{$\begin{array}{l}\text { Balkanla } \\
\text { r }\end{array}$} & \multicolumn{3}{|c|}{ Diğer } \\
\hline $\begin{array}{l}3 \\
\text { kişi }\end{array}$ & \multicolumn{3}{|c|}{48 kişi } & \multicolumn{2}{|c|}{------ } & \multicolumn{2}{|c|}{$\begin{array}{l}7 \\
\text { kişi }\end{array}$} & \multicolumn{2}{|c|}{14 kişi } & \multicolumn{2}{|c|}{8 kişi } & \multicolumn{3}{|c|}{30 kişi } & \multicolumn{2}{|c|}{6 kişi } & \multicolumn{3}{|c|}{ 11kişi } \\
\hline \multicolumn{6}{|c|}{ Sakal-Bıyık } & \multicolumn{14}{|c|}{ İsim } \\
\hline 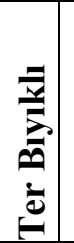 & $\frac{0}{\frac{0}{6}}$ & 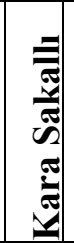 & $\overline{\mathrm{T}}$ & 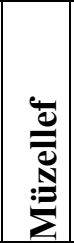 & 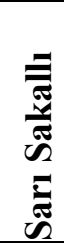 & 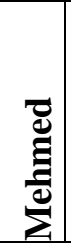 & 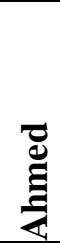 & 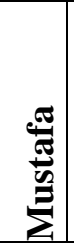 & 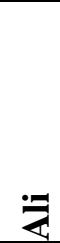 & 馬 & 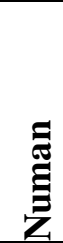 & 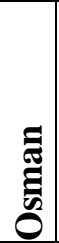 & 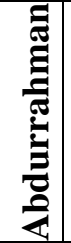 & 픞 & 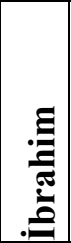 & 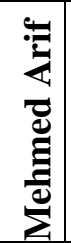 & 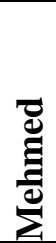 & 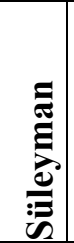 & 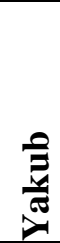 \\
\hline 5 & 14 & 9 & 6 & 6 & 4 & 9 & 6 & 5 & 3 & 3 & 3 & 3 & 2 & 2 & 2 & 1 & 1 & 1 & 1 \\
\hline
\end{tabular}

\section{Sultan Mehmed Han Tuti Abdüllatif Efendi Medresesi}

1844 yılı sayımına göre medresede 5 kişi bulunmaktadır. Medresenin yaş ortalaması 32'dir. En yaşı kişi 50, en küçük kişi ise 15 yaşındadır. Fizikî özellik olarak 3 kişi orta, 1 kişi uzun boyludur. Toplamda medresede 5 oda bulunmaktadır. 2 ve 4 numaralı odalar boştur. 1 kişi köledir. 2 kişi Selanikli, 1 kişi Erzurumludur. 1869 tarihli sayımda medresede toplamda 9 kişi kayıtlıdır. 2 müderris mevcuttur. 
Tablo 32 Medrese-i Tuti Abdüllatif Efendi Kurb-1 Sultan Mehmed Han'a Kayıtlı Olan Kişilerin Genel Özellikleri

\begin{tabular}{|c|c|c|c|c|c|c|c|c|c|c|c|c|}
\hline \multicolumn{5}{|c|}{ Yaş Aralığı } & \multicolumn{5}{|c|}{ Boy } & \multicolumn{3}{|c|}{ Memleket } \\
\hline 0-14 & & $5-39$ & \multicolumn{2}{|c|}{40 ve +} & & & \multicolumn{2}{|c|}{ Orta } & Uzun & $\begin{array}{l}\text { Anadol } \\
\text { u }\end{array}$ & $\begin{array}{l}\text { Balkanla } \\
\mathbf{r}\end{array}$ & Diğer \\
\hline ---- & & kişi & \multicolumn{2}{|c|}{2 kişi } & & - & \multicolumn{2}{|c|}{3 kişi } & 1 kişi & 1kişi & 2 kişi & ------ \\
\hline \multicolumn{4}{|c|}{ Sakal-Bıyık } & \multicolumn{6}{|c|}{ İsim } & & & \\
\hline 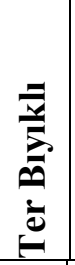 & 递 & 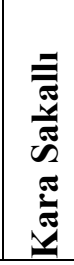 & 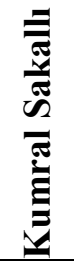 & 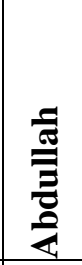 & 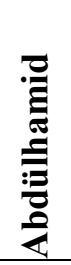 & 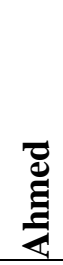 & 可 & 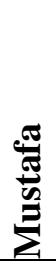 & & & & \\
\hline 1 & 1 & 1 & 2 & 1 & 1 & 1 & 1 & 1 & & & & \\
\hline
\end{tabular}

\section{Moravî Osman Efendi Medresesi}

1844 yılı sayımında medresede toplamda 26 kişi mevcuttur. 16 farklı isim kullanılmıştır. Mustafa ve Osman en fazla kullanılan isimlerdir. Medresenin yaş ortalaması 24'tür. En yaşlı kişi 52, en küçük kişi ise 17 yaşındadır. Fizikî özellik olarak 14 kişi orta, 6 kişi uzun boyludur. Medresede 8 oda vardır. 5 kişi Dramalı, 3 kişi Kavalalı, 2 kişi Berkofçalı, 2 kişi Bosnalı, 2 kişi Manastırlıdır. 1869 tarihli sayımda medresede toplamda 14 kişi kayıtlıdır. 1914 raporuna göre zemine bitişik 8 oda ile 2 barakası vardır. Barakalar kötü durumunda olup birer kişiliktir. İnşa tarzı sebebiyle iskâna uygun değildir. Avlusu geniş olduğu halde binalar arasında kalmıştır. Günümüzde arsa halindedir.

Tablo 33: Medrese-i Moravî Osman Efendi Kurb-1 Kadıçeşmesi’ne Kayıtlı Olan Kişilerin Genel Özellikleri

\begin{tabular}{|c|c|c|c|c|c|c|c|c|c|c|c|c|c|c|c|c|c|c|c|c|c|}
\hline \multicolumn{6}{|c|}{ Yaş Aralığı } & \multicolumn{7}{|c|}{ Boy } & \multicolumn{9}{|c|}{ Memleket } \\
\hline $\begin{array}{l}0- \\
14\end{array}$ & \multicolumn{3}{|c|}{$15-39$} & $\begin{array}{l}40 \\
+\end{array}$ & & \multicolumn{2}{|c|}{ Kisa } & \multicolumn{3}{|c|}{ Orta } & \multicolumn{2}{|c|}{ Uzun } & \multicolumn{3}{|c|}{ Anadolu } & \multicolumn{3}{|c|}{$\begin{array}{l}\text { Balkanla } \\
\mathbf{r}\end{array}$} & \multicolumn{3}{|c|}{ Diğer } \\
\hline -.-. & \multicolumn{3}{|c|}{24 kişi } & 2 kiş & & \multicolumn{2}{|c|}{----} & \multicolumn{3}{|c|}{14 kişi } & \multicolumn{2}{|c|}{6 kişi } & \multicolumn{3}{|c|}{6 kişi } & \multicolumn{3}{|c|}{16 kişi } & \multicolumn{3}{|c|}{4 kişi } \\
\hline \multicolumn{6}{|c|}{ Sakal-Bıyık } & \multicolumn{16}{|c|}{ İsim } \\
\hline 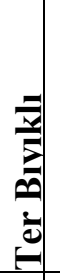 & $\frac{0}{8}$ & 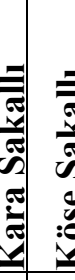 & $=$ & 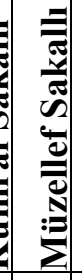 & 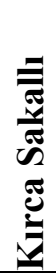 & & 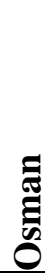 & 递 & 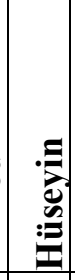 & 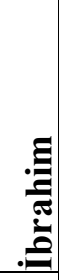 & 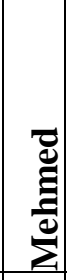 & $\begin{array}{l}\frac{1}{\pi} \\
\overline{\mathbf{E}} \\
\overline{\mathbf{E}} \\
\end{array}$ & 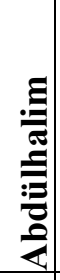 & $\frac{8}{2}$ & 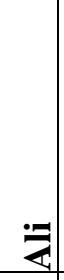 & : & : & $\begin{array}{c}\tilde{\Xi} \\
\overline{\mathbf{Z}} \\
\mathbf{Z}\end{array}$ & $\begin{array}{c}\frac{5}{7} \\
\text { : } \\
\text { : }\end{array}$ & 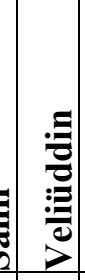 & 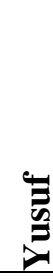 \\
\hline 1 & 5 & 1 & 7 & 7 & 1 & 5 & 3 & 2 & 2 & 2 & 2 & 1 & 1 & 1 & 1 & 1 & 1 & 1 & 1 & 1 & 1 \\
\hline
\end{tabular}




\section{Said Ahmed Efendi Medresesi}

1844 y1lı sayımına göre medresede 34 kişi mevcuttur. 13 farklı isim kullanılmıştır. Mustafa, Ahmet, İsmail en fazla kullanılan isimlerdir. Bir kişi çift isimlidir (Abdullah Reşid). Medresenin yaş ortalaması 23'tür. En yaşlı kişi 55, en küçük kişi ise 15 yaşındadır. Fizikî özellik olarak 19 kişi orta, 6 kişi uzun boyludur. Toplamda 10 odası vardır. 4, 5, 7 ve 9 numaralı odalar boştur. 1 bevvab vardır. Büyük ölçüde Balkanlardan gelen kişilerin bulunduğu medresede 7 kişi Bosnalı, 5 kişi Berkofçalı, 4 kişi Dramalı, 2 kişi Kavalalı, 2 kişi ise Zağra-i Atiklidir.

Tablo 34: Medrese-i Said Ahmed Efendi Kurb-1 Kadıçeşmesi’ne Kayıtlı Olan Kişilerin Genel Özellikleri

\begin{tabular}{|c|c|c|c|c|c|c|c|c|c|c|c|c|c|c|c|c|c|c|c|c|c|}
\hline \multicolumn{6}{|c|}{ Yaş Aralığı } & & \multicolumn{6}{|c|}{ Boy } & \multicolumn{9}{|c|}{ Memleket } \\
\hline \multicolumn{2}{|l|}{$\begin{array}{l}0- \\
14\end{array}$} & \multicolumn{2}{|c|}{$15-39$} & \multicolumn{3}{|c|}{$40 \mathrm{ve}+$} & \multicolumn{2}{|c|}{ Kisa } & \multicolumn{2}{|c|}{ Orta } & \multicolumn{2}{|c|}{ Uzun } & \multicolumn{3}{|c|}{ Anadolu } & \multicolumn{3}{|c|}{$\begin{array}{l}\text { Balkanla } \\
\text { r }\end{array}$} & \multicolumn{3}{|c|}{ Diğger } \\
\hline \multicolumn{2}{|c|}{$\begin{array}{l}--- \\
- \\
\end{array}$} & \multicolumn{2}{|c|}{32 kişi } & \multicolumn{3}{|c|}{1 kişi } & \multicolumn{2}{|c|}{----- } & \multicolumn{2}{|c|}{19 kişi } & \multicolumn{2}{|c|}{6 kişi } & \multicolumn{3}{|c|}{7 kişi } & \multicolumn{3}{|c|}{26 kişi } & \multicolumn{3}{|c|}{------- } \\
\hline \multicolumn{10}{|c|}{ Sakal-Bıyık } & \multicolumn{12}{|c|}{ İsim } \\
\hline $\begin{array}{l}\frac{z}{3} \\
\frac{1}{2} \\
\frac{2}{2}\end{array}$ & 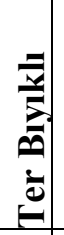 & 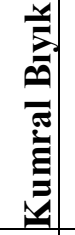 & $\frac{0}{\frac{0}{6}}$ & 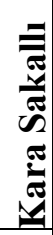 & 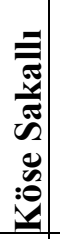 & 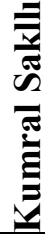 & $\frac{}{\bar{d}}$ & 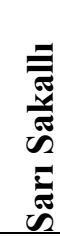 & 惫 & $\frac{\vec{E}}{E}$ & 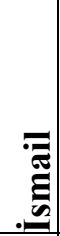 & 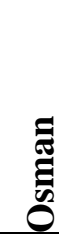 & 节. & $\because$ & : & 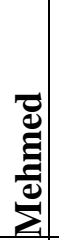 & 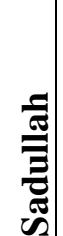 & $\underset{\nabla}{\mathbb{\pi}}$ & : & 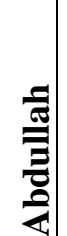 & $=$ \\
\hline 1 & 3 & 1 & 6 & 4 & 1 & 8 & 2 & 3 & \begin{tabular}{|l|l|}
7 \\
\end{tabular} & 5 & 4 & 4 & 3 & 2 & 2 & 1 & 1 & 1 & 1 & 1 & 1 \\
\hline
\end{tabular}

\section{5. Çayırlı Medresesi}

Medresede 1844 yılı sayımında 22 kişi bulunmaktadır. 13 farklı isim kullanılmıştır. Medresenin yaş ortalaması 26'dır. En yaşlı kişi 55, en küçük kişi ise 18 yaşındadır. Fizikî özellik olarak 11 kişi orta, 4 kişi uzun boyludur. Medresede 8 oda bulunmaktadır. Genellikle Balkanlardan gelen kişilerin bulunduğu medresede 3 kişi Kazanlık, 3 kişi Tikveş, 2 kişi ise Hezardrad'tan gelmiştir. 1869 tarihli sayıma göre medresede 33 kişi kayıtlıdır. 1914 raporuna göre odaları zeminden yüksek olup alt kısmı kömürlük halindedir. 17 ahşap odadan oluşmaktadır. İskâna uygun değildir. Günümüzde arsa halindedir. 
Tablo 35: Medrese-i Çayırlı Der-Nezd-i Kadıçeşmesi’ne Kayıtlı Olan Kişilerin Genel Özellikleri

\begin{tabular}{|c|c|c|c|c|c|c|c|c|c|c|c|c|c|c|c|c|c|c|c|}
\hline \multicolumn{6}{|c|}{ Yaş Aralığı } & \multicolumn{6}{|c|}{ Boy } & \multicolumn{8}{|c|}{ Memleket } \\
\hline \multicolumn{2}{|c|}{$0-14$} & \multicolumn{2}{|c|}{$15-39$} & \multicolumn{2}{|c|}{40 ve +} & \multicolumn{2}{|c|}{$\begin{array}{l}\text { Kis } \\
\text { a }\end{array}$} & \multicolumn{2}{|c|}{ Orta } & \multicolumn{2}{|c|}{$\begin{array}{l}\text { Uzu } \\
\text { n }\end{array}$} & \multicolumn{2}{|c|}{$\begin{array}{l}\text { Anadol } \\
\text { u }\end{array}$} & \multicolumn{3}{|c|}{$\begin{array}{l}\text { Balkanla } \\
\text { r }\end{array}$} & \multicolumn{3}{|c|}{ Diğer } \\
\hline \multicolumn{2}{|c|}{---- } & \multicolumn{2}{|c|}{20 kişi } & \multicolumn{2}{|c|}{2 kişi } & \multicolumn{2}{|c|}{---- } & \multicolumn{2}{|c|}{11 kişi } & \multicolumn{2}{|c|}{$\begin{array}{l}4 \\
\text { kişi }\end{array}$} & \multicolumn{2}{|c|}{8 kişi } & \multicolumn{3}{|c|}{14 kişi } & \multicolumn{3}{|c|}{------- } \\
\hline \multicolumn{8}{|c|}{ Sakal-Bıyık } & \multicolumn{12}{|c|}{ İsim } \\
\hline 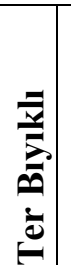 & $\frac{0}{0}$ & 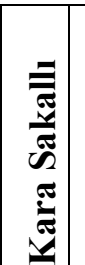 & 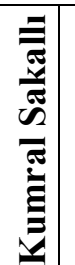 & 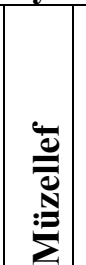 & 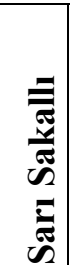 & 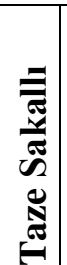 & & 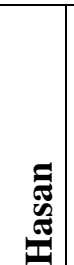 & 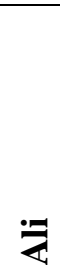 & 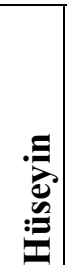 & $\frac{\text { Ded }}{\text { De }}$ & 胥 & 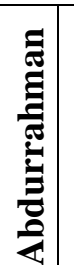 & 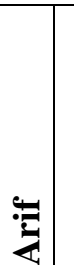 & : & قٍ & 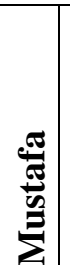 & 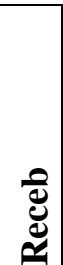 & 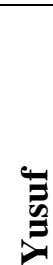 \\
\hline 2 & 3 & 4 & 7 & 1 & 2 & 1 & 4 & 3 & 2 & 2 & 2 & 2 & 1 & 1 & 1 & 1 & 1 & 1 & 1 \\
\hline
\end{tabular}

\section{Mimar Sinan Yusuf Efendi Medresesi}

Medresede 1844 sayımına göre 19 kişi bulunmaktadır. 12 farklı isim kullanılmıştır. Ali ve Mehmet en fazla kullanılan isimlerdir. Medresenin yaş ortalaması $25^{\prime}$ tir. En yaşlı kişi 40 yaşında, en küçük kişi ise 13 yaşındadır. Fizikî özellik olarak 11 kişi orta, 2 kişi uzun boyludur. Medresede toplamda 7 oda vardır. Oda numaralı düzenli değildir. 1914 raporuna göre 10 odası vardır. Odalar yüksek olup alt kısım kömürlük halindedir. Avlusunda cami ve türbe mevcuttur. Günümüzde arsa halindedir.

Tablo 36: Medrese-i Mimar Sinan Yusuf Efendi Kurb-1 Aşık Paşa’ya Kayıtlı Olan Kişilerin Genel Özellikleri

\begin{tabular}{|c|c|c|c|c|c|c|c|c|c|c|c|c|c|c|c|c|c|}
\hline \multicolumn{6}{|c|}{ Yaş Aralı̆̆ } & \multicolumn{5}{|c|}{ Boy } & \multicolumn{7}{|c|}{ Memleket } \\
\hline $0-14$ & \multicolumn{3}{|c|}{ 15-39 } & \multicolumn{2}{|c|}{40 ve +} & Kisa & \multicolumn{2}{|c|}{ Orta } & \multicolumn{2}{|c|}{$\begin{array}{l}\text { Uzu } \\
\text { n }\end{array}$} & \multicolumn{2}{|c|}{$\begin{array}{l}\text { Anadol } \\
\text { u }\end{array}$} & \multicolumn{2}{|c|}{$\begin{array}{l}\text { Balkanla } \\
\mathbf{r}\end{array}$} & \multicolumn{3}{|c|}{ Diğer } \\
\hline $\begin{array}{l}1 \\
\text { kişi }\end{array}$ & \multicolumn{3}{|c|}{17 kişi } & \multicolumn{2}{|c|}{1 kişi } & ---- & \multicolumn{2}{|c|}{$\begin{array}{l}11 \\
\text { kişi }\end{array}$} & \multicolumn{2}{|c|}{$\begin{array}{l}2 \\
\text { kiși }\end{array}$} & \multicolumn{2}{|c|}{13 kişi } & \multicolumn{2}{|c|}{---- } & \multicolumn{3}{|c|}{6 kişi } \\
\hline \multicolumn{6}{|c|}{ Sakal-Bıyık } & \multicolumn{12}{|c|}{ İsim } \\
\hline 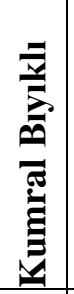 & $\frac{0}{2 \pi}$ & 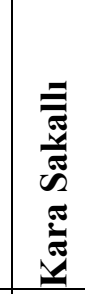 & 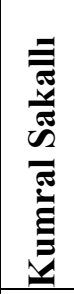 & 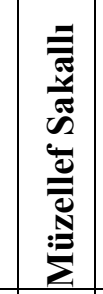 & 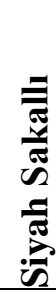 & $\bar{z}$ & 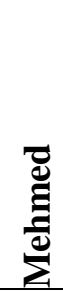 & 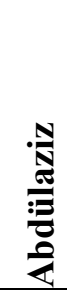 & $\underset{\Xi}{E}$ & : & 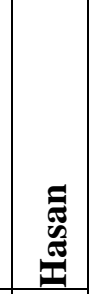 & 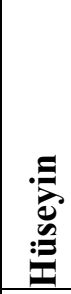 & 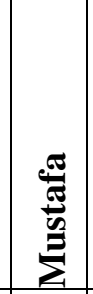 & 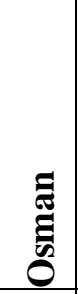 & పే & 总 & 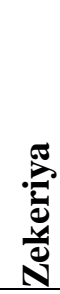 \\
\hline 1 & 2 & 6 & 6 & 3 & 1 & 5 & 4 & 1 & 1 & 1 & 1 & 1 & 1 & 1 & 1 & 1 & 1 \\
\hline
\end{tabular}




\section{Huffâz Şemseddin Medresesi}

1844 sayımında medresede Kastamonulu 1 kişi vardır. Defterde başka bir bilgiye ulaşılamamıştır.

Tablo 37: Medrese-i Huffâz Şemseddin Kurb Bâb-1 Ayazma’ya Kayıtlı Olan Kişilerin Genel Özellikleri

\begin{tabular}{|c|c|c|c|c|c|c|c|c|}
\hline \multicolumn{3}{|c|}{ Yaş Aralığı } & \multicolumn{3}{|c|}{ Boy } & \multicolumn{3}{|c|}{ Memleket } \\
\hline $0-14$ & $\begin{array}{l}15- \\
39\end{array}$ & 40 ve + & Kisa & Orta & Uzun & Anadolu & Balkanlar & Diğer \\
\hline ---- & 1 kişi & ------ & ------ & 1 kişi & ----- & 1 kişi & ---- & ---- \\
\hline \multicolumn{2}{|c|}{ Sakal-Bıyık } & \multicolumn{7}{|l|}{ İsim } \\
\hline 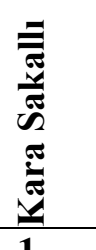 & & 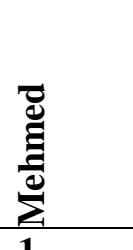 & & & & & & \\
\hline 1 & & 1 & & & & & & \\
\hline
\end{tabular}

\section{Sonuç}

Osmanlı Devleti'nde nüfus sayımı değişik amaçlar için yapılmıştır. Bu amaçlardan bir tanesi de medresede bulunan kişilerin sayısını tespit etmektir. Çünkü Tanzimat Fermanı'nın ilanıyla birlikte askerlik, vatan hizmeti haline gelince toplumun belli bir kesimi medreseye akın ederek askerlikten muaf olmak istemiştir. Zira yapmış olduğumuz çalışmada, medreselerde kayıtlı bulunan kişilerin yaş ortalaması bunu destekler niteliktedir. Yaş ortalaması genel itibariyle 23-28 yaş arasını kapsamaktadır. Osmanlı Devleti'nde resmî olarak askere alma yaşı 15 idi. Buradan hareketle medreseye kayıtlı olan kişilerin askerlikten muaf olma yolunu seçtiklerini söylemek mümkündür. Medreselerdeki bu yoğunluk üzerine, bir müddet sonra devlet, duruma müdahale edip askere alma ile ilgili medresede kişiler arasında kura usulüne yönelik bir kanun çıkartmıştır (1844-1846). Kanuna göre, medresedeki kişilerden sınava tabi tutulup başarılı olanlar medresede kalarak eğitimlerine devam etmiş başarılı olmayanlar askere alınmıştır.

Osmanlı nüfus defterlerinin araştırmacıya açılmasıyla bu konuda birçok çalışma yapılmıştır ve yapılmaya da devam edilmektedir. Ancak İstanbul Medreseleri Nüfus Defterleriyle ilgili fazla bir çalışma yoktur. Başbakanlık Osmanlı Arşivi kataloğunda 16 adet medrese nüfus defteri mevcuttur. Bunlardan yalnızca 185 numaralı İstanbul medreseleri nüfus defteri incelenmiştir. Bu tarihte İstanbul'da toplam medrese adedini 
ve talebe sayısını tespit edebilmek için defterlerin tamamının inceleme zorunluluğu doğmaktadır. Her ne kadar medreselerle ilgili çalışmalar yapılmışsa da özelde İstanbul medreseleriyle ilgili yeterince detaylı çalışma bulunmamaktadır. İncelemiş olduğumuz tetkik eserlerin bazılarında İstanbul medreseleriyle ilgili değişik tarihlerde yapılan nüfus sayımlarıyla ilgili bir takım verilere ulaşmak mümkündür. İncelediğimiz 1844 yılına ait 187 numaralı medrese nüfus defterinde 37 adet medrese bulunmaktadır. Bu defterde adı geçen bazı medreselerden günümüze ulaşanlardan tespit edebildiklerimizden bazıları şunlardır: Süleymaniye Dâru'l Hadis Medresesi, günümüze ulaşmış fakat özgün görünümünü kaybetmiştir. Aziziye Sosyal Dayanışma Kültür ve Eğitim vakfına tesis edilmiştir. Süleymaniye Mülâzımlar Medresesi, günümüzde mevcut olmakla birlikte kullanılmamaktadır. Süleymaniye Evvel Medresesi bugün Süleymaniye Kütüphanesi olarak kullanılmaktadır. Zemin kat ise ticarî işler için tahsis edilmiştir. Süleymaniye Râbia Medresesi, şu anda TÜBA tarafindan restore edilmektedir. Siyavuş Paşa Medresesi, bugün oldukça bakımsız bir durumda olan medresenin bazı bölümleri atölye ve depo olarak kullanılmaktadır. Şeyh Ebu'l-Vefa Medresesi, Doğu ve Güneydoğu Anadolu'dan göç eden ailelerin mesken olarak kullandığı binaların arasında kalmaktadır. Kuyucu Murad Paşa Medresesi, günümüzde İstanbul Üniversitesi Güzel Sanatlar Bölümü binası olarak kullanılmaktadır. Amucazâde Hüseyin Paşa Medresesi, 1967'den itibaren Türk İnşaat ve Sanat Eserleri Müzesi olarak kullanılmaktadır. 


\section{KAYNAKÇA}

\section{Arşiv Kaynakları}

Başbakanlık Osmanlı Arşivi, NFS.d 187 Numaralı Medrese Nüfus Defteri.

\section{Tetkik Eserler Ve Makaleler}

BALCI, Ramazan, “Medreselerin Islahı Konusunda Sultan II.Abdülhamit'in Hazırlattığ Bir Lahiyanın Tahlili”, Tarih Okulu, Sayı: 12, Ocak-Nisan 2012, s. 155-191.

BALTACI, Cahit, "Medrese ve Elemanları", Diyanet Dergisi, Cilt: XVI, Sayı: 3, Mayıs-Haziran 1977, s.133-141. , “Klasik Dönem Osmanlı İlim Müesseseleri”, İslamî Araştırmalar

Dergisi, Cilt: 12, Say1: 3-4, Ankara 1999, s. 259-262.

BİNGÖL Sedat, 1829 İstanbul Nüfus Sayımı ve Tophane Kasabası, Eskişehir 2004. , “İstanbul’da 1829 Nüfus Sayımı ve Bazı Mahallelerin Müslüman

Nüfusu Üzerine Bir İnceleme", Ankara Üniversitesi Dil ve Tarih-Coğrafya Fakültesi Tarih Bölümü Tarih Araştırmaları Dergisi, Cilt: 23, Sayı: 36, Ankara 2004, s. 43-60.

ÇAKAR, Enver, “Tahrir Defterlerine Göre XVI. Yüzyılda Humus Şehri”, Fırat

Üniversitesi Sosyal Bilimler Dergisi, Cilt: 13, Sayı: 2, Elazığ 2003, s. 375-392.

ÇİMEN, Adnan, "Sayım, Kayıt Düzeni ve Teşkilatlanma Açısından Osmanlıda Nüfus

Hizmetleri”, Gazi Üniversitesi İktisadi ve İdari Bilimler Fakültesi Dergisi, 14/3, Ankara 2012, s. 183-216.

ÇATAKOĞLU, M. Şerif, Anadolu Selçuklu Dönemi İlmi Faaliyetleri ve Bu Faaliyetlerin Osmanlı Kuruluş Dönemi İlmi Faaliyetlerine Tesiri, Süleyman Demirel Üniversitesi Sosyal Bilimler Enstitüsü, Yüksek Lisans Tezi, Isparta 2002.

ÇİMEN, Adnan, "Sayım, Kayıt Düzeni ve Teşkilatlanma Açısından Osmanlıda Nüfus Hizmetleri”, Gazi Üniversitesi İktisadi ve İdari Bilimler Fakültesi Dergisi, 14/3, Ankara 2012, s. 183-216.

DEVELLIOĞLU, Ferit, Osmanlıca-Türkçe Ansiklopedik Lügat, Aydın Kitabevi, Ankara 1993.

DOĞAN, Recai, “Osmanlı Eğitim Kurumları ve Eğitimde İlk Yenileşme Hareketlerinin Batılılaşma Açısından Tahlili”, Ankara Üniversitesi İlahiyat Fakültesi Dergisi, Cilt: 37, Sayı: 1, Ankara 1997, s.407-442. 
GELİŞLİ, Yücel, “On Dokuzuncu Yüzyılda Osmanlı Devleti’nin Bağdat ve Yemen Vilayetlerinde Medreselerin Açılma Gerekçelerine İlişkin İki Belge”, Gazi Üniversitesi Gazi Eğitim Fakültesi Dergisi, Cilt: 25, Sayı: 2, Ankara 2005, s. 83-113.

GÖLEÇ, Mustafa - GÜLDAL, Fatih, İstanbul'un 100 Mektebi ve Medresesi, İstanbul'un Yüzleri Serisi-50, İstanbul Büyükşsehir Belediyesi, İstanbul 2012.

HIZLI, Mefail, “Kuruluşundan Osmanlılara Kadar Medreseler”, Uludağ Üniversitesi İlahiyat Fakültesi Dergisi, Cilt: 2, Sayı: 2, Bursa 1987, s. 273-281. , "Osmanlı Medreselerinde Okutulan Dersler ve Eserler", Uludă Üniversitesi İlahiyat Fakültesi Dergisi, Cilt: 17, Say1: 1, Bursa 2008, s. 25-46. İNALCIK, Halil, Osmanı İmparatorluğu Klasik Çağ (1300-1600), Çeviren: R.Sezer, YKY yayınları, İstanbul 2008.

KARAL, Enver Ziya, Osmanlı İmparatorluğunda İlk Nüfus Sayımı 1831, Ankara 1997.

KÜTÜKOĞLU, Mübahat S., “Darü'l-Hilafeti'l-Aliyye Medreseleri ve Kuruluş Arefesinde İstanbul Medreseleri”, ITTED, İstanbul 1978.

KÜTÜKOĞLU, Mübahat S., “1869'da Faal İstanbul Medreseleri”, Tarih Enstitüsü Dergisi, Sayı 7-8, Edebiyat Fakültesi Matbaası, İstanbul 1977, s. 277-392.

ÖZKAN, Şerife, Medrese Tabirinin İlk Defa Ortaya Çıkışı, Selçuklular Zamanında Medreselerin Kuruluş Sebepleri ve Medrese Eğitimi, Selçuk Üniversitesi, Yayımlanmamış Yüksek Lisans Tezi, Konya 2007.

TAŞKIN Ünal, "Klasik Dönem Osmanlı Eğitim Kurumları”, Uluslararası Sosyal Araştırmalar Dergisi, Volume 1/3Sprıng, 2008, s. 344-366.

UZUNÇARŞILI, İsmail Hakkı, Osmanlı Devleti’nin İlmiye Teşkilatı, Ankara 1988. ZORLU, Tuncay, "Klasik Osmanlı Eğitim Sisteminin İki Büyük Temsilcisi: Fatih ve Süleymaniye Medreseleri”, Türkiye Araştırmaları Literatür Dergisi, Cilt 6, Sayı 12, 2008, s. 611-628. 